\title{
Nine New Painted Rock Art Sites from East Timor in the Context of the Western Pacific Region
}

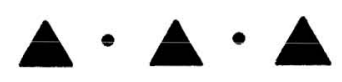

SUE O'CONNOR

NINE NEW PAINTED ROCK ART SITES were located in East Timor during reconnaissance over two field seasons in July-August 2000 and July-September 2001 (O'Connor et al. 2002, Fig. 1, sites 5-11 and 14-15). This paper provides a preliminary report on these sites in the context of previously recorded rock art sites in East Timor and comparisons are made with some other areas of painted rock art in the western Pacific (defined here after Wilson (2002:10) as including the area from Timor in the west to Tonga and Samoa in the east).

Prior to finding the nine new sites, only six painted rock art sites were known for East Timor. These were recorded by the Portuguese anthropologists Cinatti (1963) and Almeida (1967) in the early 1960s, and by Ian Glover (1986) during the course of his doctoral fieldwork in 1966-1967. All are located on, or near, the north or northeast coasts of East Timor. Following Indonesian occupation in 1975, East Timor was closed to non-Indonesian researchers. The preliminary descriptions contained herein are the first rock art descriptions undertaken for 25 years. The nine new sites located bring the total number of art sites known for East Timor to 15 and indicate that many more sites will probably be found with systematic survey. The faded and deteriorated condition of many of the paintings indicates that standard and enhanced recording (David et al. 2001) should be undertaken with some urgency.

Following Ballard (1992) the relationship between the art, topography, and language groups for the new sites is described. The context of the East Timor art sites and their design elements are compared in a preliminary fashion with that of other painting sites known from East Timor and parts of the western Pacific and are evaluated within the framework of what Ballard has termed the "Austronesian painting tradition" (Ballard 1992:94). While in many respects the East Timor sites are conformable with Austronesian painted rock art sites elsewhere in the western Pacific they also display some regionally distinctive features. For example, the East Timor painting sites contain proportionally fewer hand and other stencils than the

Sue O'Connor is Senior Fellow, Department of Archaeology and Natural History, Research School of Pacific and Asian Studies, Australian National University, Canberra. 


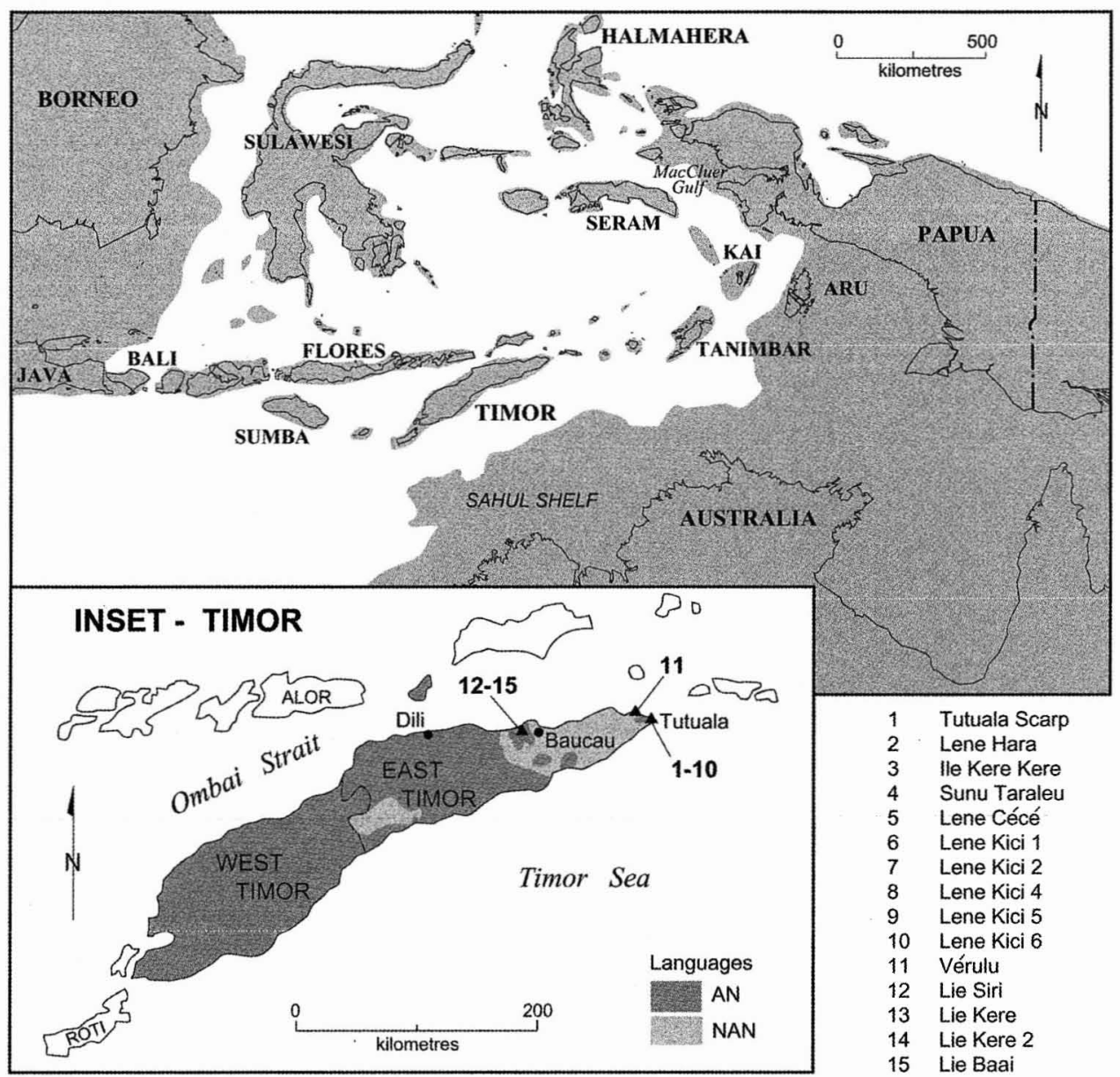

Fig. 1. East Timor art sites (newly recorded sites are 5-10,13-14). Map also shows the current distribution of AN and NAN language areas.

painted rock art sites to the east of Timor (Ballard 1988; Röder 1956). There are also contextual differences. Most Austronesian painted panels are remarkable for their inaccessibility, with motifs often placed high on the walls of shallow seacliffs. While some paintings in East Timor are found in such inaccessible locations, there is also a distinct group of painted motifs - most of the hand stencils and some simple red figurative motifs-found in accessible locations on the walls within solution caves.

Although none of the art in the East Timor sites has been directly dated, many motifs have stylistic affinities with painted art elsewhere in the western Pacific that post-dates Austronesian expansion (Wilson 2002), and with motifs found on Metal Age objects recovered from surface contexts in Island Southeast Asia, such as Dong Son drums. This may indicate an age of 2000 B.P. or later for some of the motifs. The depiction of horses, which may have had a historic period introduction to East Timor (Glover 1986:11), demonstrate that painting was a continuing tradition in this region. 
When the East Timor Archaeological Project (ETAP) commenced in July 2000 no archaeological work in this region had been published since Glover's 19661967 excavation reports (Glover 1986). In the past two years, over 70 cave and open sites have been recorded, including the nine new painting sites described below. Three of the cave sites and one open shell midden have been excavated and dated and several open surface middens have been dated. The excavated cave sites are Lene Hara, at the east end of East Timor near Tutuala, and Matja Kuru 1 and 2 near Poros, also near the east end of the island. To date, only preliminary results from Lene Hara cave (O'Connor et al. 2002, n.d.), and one of the open midden sites (O'Connor 2002) have been published.

Lene Hara was originally excavated by Almeida in the 1960s, however, he published only a brief description of some of the stone artifacts and no radiocarbon dates were obtained (Almeida and Zbyszewski 1967). The dates returned from the basal cultural deposits of Lene Hara, following the ETAP's 2000 excavation season, demonstrate human occupation of the cave from about 35,000 years ago (34,650 \pm 630 ANU-11418) (O'Connor et al. 2002). Lene Hara has a cultural sequence with marine shell, vertebrate fauna, and stone artifacts to a depth of about $85 \mathrm{~cm}$. Pottery is found predominantly in the upper $20 \mathrm{~cm}$ of the site which dates to the last 2000 years. The 35,000 B.P. date more than doubles the previous known date for human occupation in East Timor, obtained by Glover (1986:167).

Glover excavated a number of sites in the Baucau and Venilale areas, among them is the art site Lie Siri, discussed below. The oldest of his sites, Uai Bobo 2, near Venilale, dated to $13,420 \pm 520$ B.P. (ANU-238) and contained endemic fauna and stone artifacts in the Pleistocene and Holocene levels, with the addition of pottery and domestic animals from approximately 4000 B.P. (Glover 1986:161194). Several of the endemic species disappear from the sequence in the last few thousand years, probably as a result of habitat destruction. While the Neolithic levels in Glover's sites contained a variety of shell artifacts, he notes that there was little indication of the Metal Age in any of his excavations. He attributes this largely to the fact that caves are not very representative of the full range of activities of sedentary horticulturalists and "value goods" are rarely uncovered in them (Glover 1986). He did recover a Dong Son socketed axe from the surface of a shelter site near Baucau Township during his survey. ${ }^{1}$

As well as carrying out archaeological excavations, both Almeida (1967) and Glover (1972) recorded a range of sites containing painted art. Almeida (1967) recorded the rock art in Lene Hara cave and the overhangs Tutuala Scarp, Ile Kere Kere, and Sunu Taraleu Scarp, all near Tutuala (see also Cinatti 1963). The Tutuala and Sunu Taraleu Scarp sites are, as their names suggest, narrow overhangs in the high raised limestone terraces overlooking the sea. They contain paintings mostly executed in red pigment which include geometrics such as stars and radiating circles, as well as boats (Fig. 2), and small anthropomorphic figures shown in dancing or fighting attitudes-many with weapons or other objects in their hands (Almeida 1967 :figs. 1-3). Similar red anthropomorphs and boats are depicted at Ile Kere Kere, another exposed overhang in an uplifted coral terrace facing the sea. Black art also occurs here, albeit less commonly than red, and one 


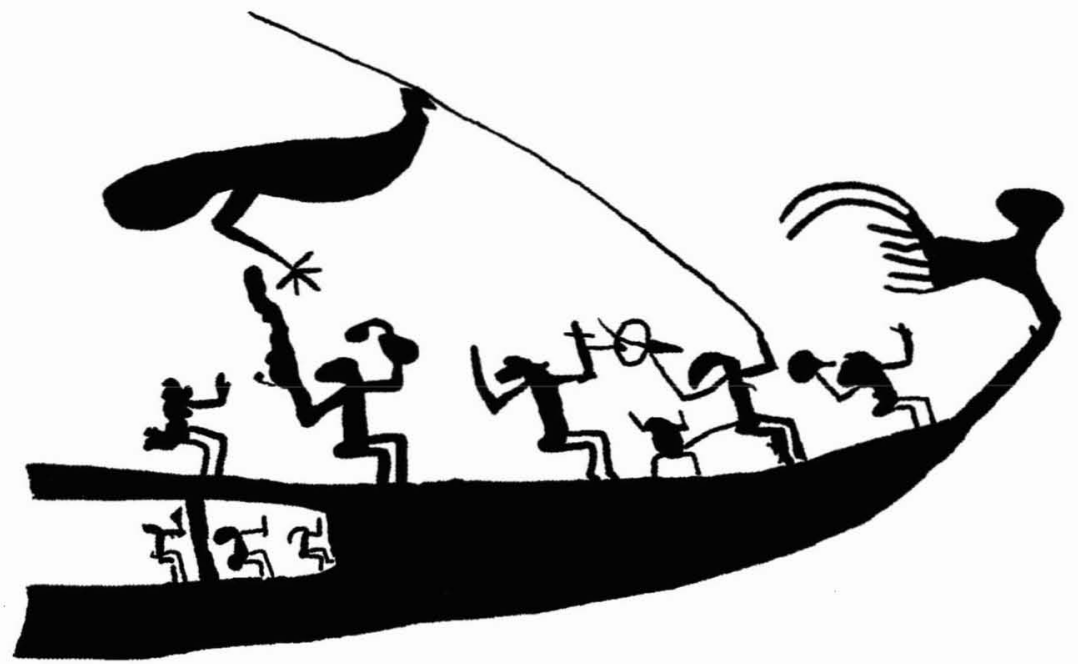

Fig. 2. Dong Son x-ray style boat and "cassowary" in red pigment at Lene Cécé.

design is polychrome with red, black, yellow, and green pigment used. Zoomorphic representations include what Almeida (1967:69) describes as "a ray" and "a coelenterate." Almeida reports a single hand stencil at Ile Kere Kere. Lene Hara is somewhat different from the other sites. It is a large deep solution cave about $100 \mathrm{~m}$ above sea level located in secondary forest over $1 \mathrm{~km}$ inland from the coast (Fig. 3). While it contains some anthropomorphic figures, most of the paintings are decorative linear motifs and some are a composite of both (Fig. 4). Almeida reported hand stencils and some zoomorphic representations, among which he

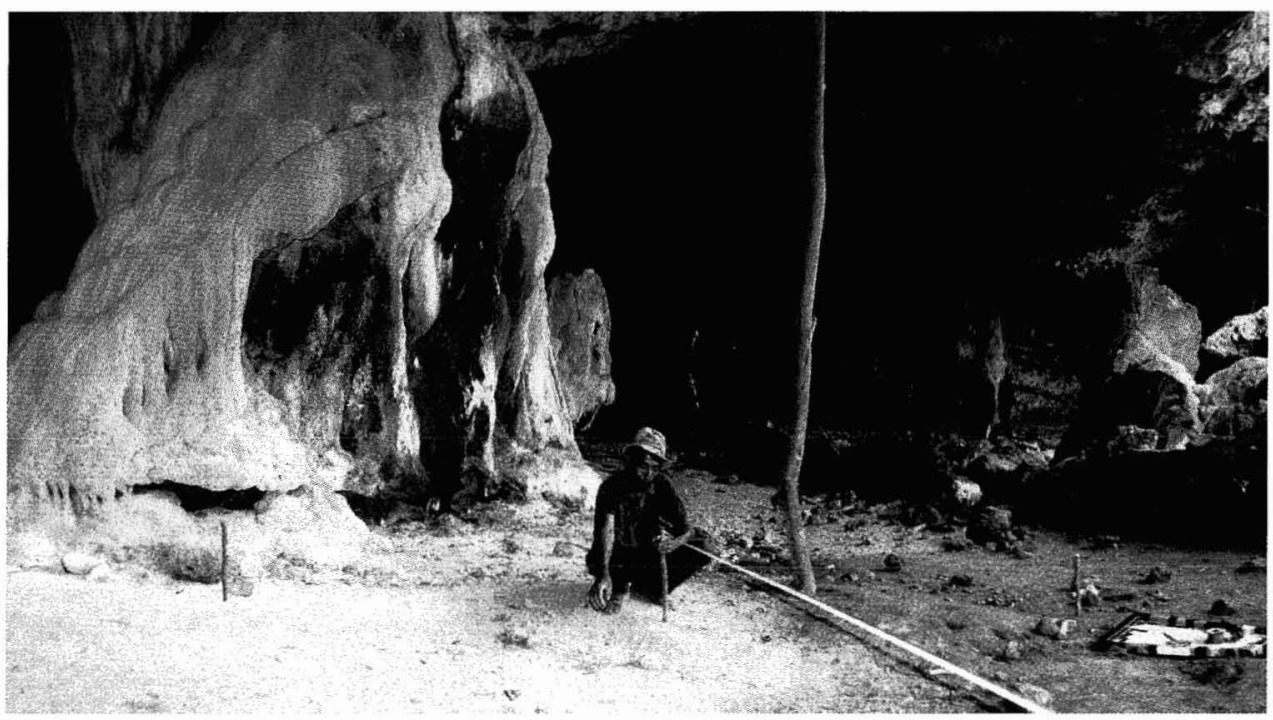

Fig. 3. Lene Hara cave: many of the paintings are on the ceiling above the large stalagmite formation to the left rear of the photograph. 

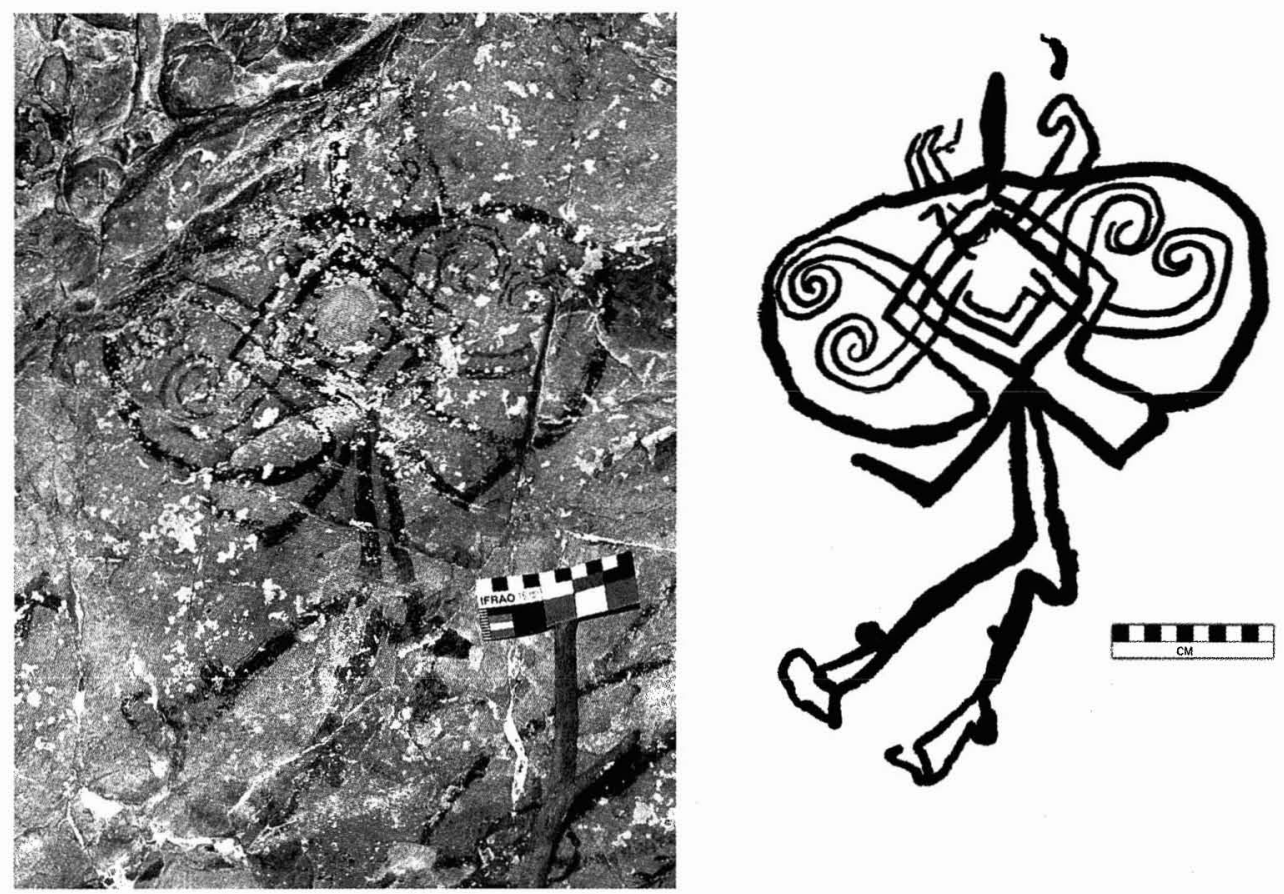

Fig. 4. Lene Hara cave: photograph and outline drawing of anthropomorph with complex scrolled linear design in place of head (red pigment).

noted "x-ray" fish (Figs. 5, 6). The latter he thought bore similarities to the x-ray figures of Arnhem Land and considered that they may have totemic significance. However, as will be discussed below, similar x-ray depictions of fish are featured in the MacCluer Gulf painted panels in Papua (formerly Irian Jaya).

The dominant colors in Lene Hara are red and black, with red again most common. One of the linear motifs in red and black includes a faded green infill (Fig. 7). Almeida refers to this motif as representing "a pair of tortoises devouring a fish." To the left of the polychrome linear design, and seemingly in contact with it, is a red anthropomorphic figure holding a bow in its right hand and an indeterminate object in its left hand.

Almeida (1967:71) comments that the red hematite is potentially available in the vicinity of the scarp sites and Lene Hara. No mention is made of the source of the green pigment used in the polychrome figures at Lene Hara and Ile Kere Kere but it is possibly derived from copper. Copper deposits were mined in Timor in the historic past (Van Es 1921) and copper-rich rocks are found occasionally as beach pebbles on the north coast.

Almeida concluded that although pictorial characteristics are shared between all four sites, Sunu Taraleu, Ile Kere Kere, and Tutuala Scarp show the greatest similarities, particularly in the range of red anthropomorphic figures portrayed dancing or fighting; combined in scenes of "an impressively dynamic realism" (Almeida 1967:73). Both Cinatti (1963) and Almeida (1967:70) recognized similarities between the art of East Timor and that elsewhere in Island Southeast Asia 

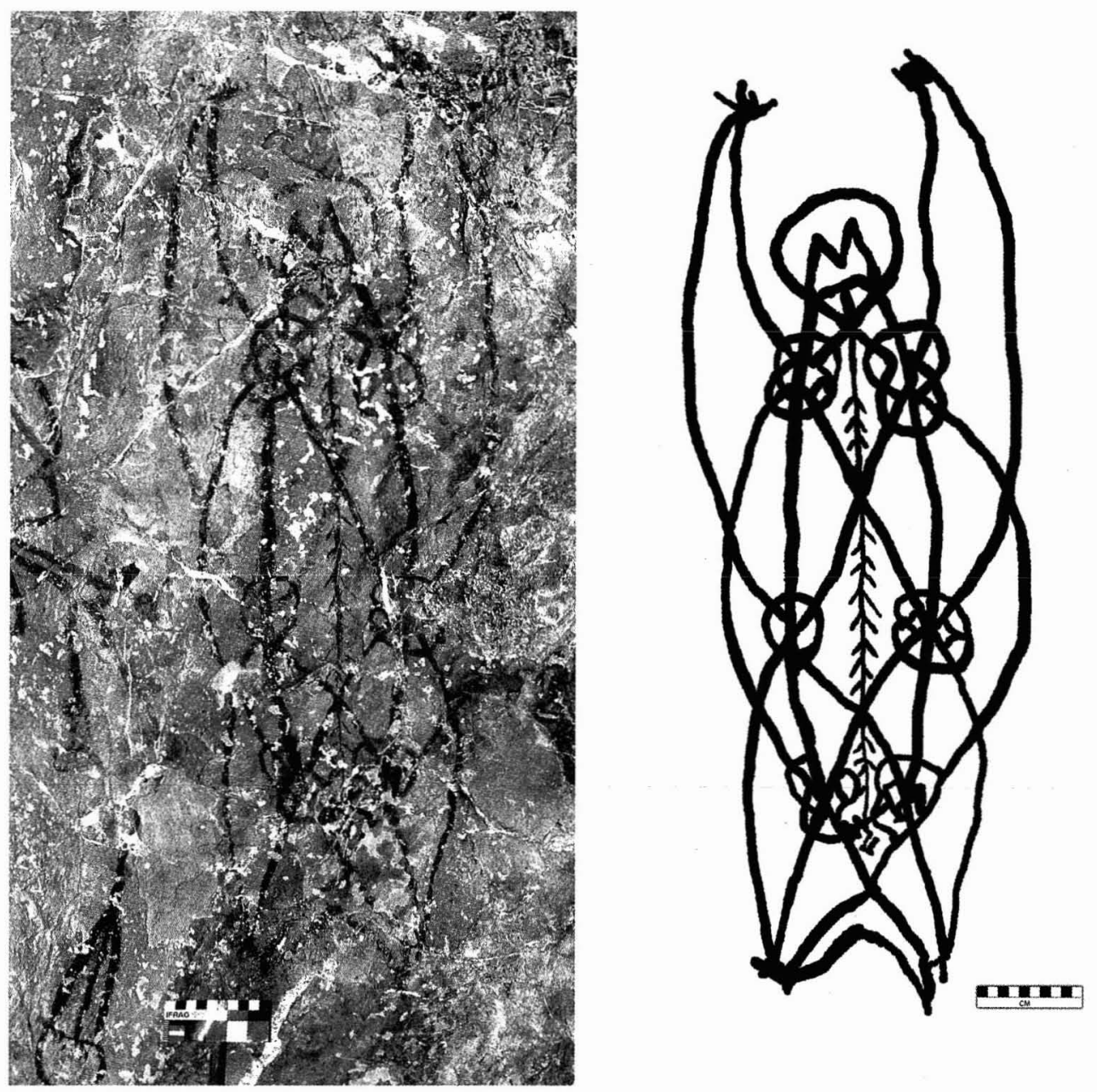

Fig. 5. Lene Hara cave: photograph and drawing of $x$-ray fish-outline flying fox (red pigment).

and postulated some type of cultural interaction across this region. All four sites are in a region where Fata Luku, a Papuan language, is spoken today (see fig. 1), however, Almeida (1967:71) notes that the area was formerly inhabited by Makowe (also Makua) people, who died out or departed permanently.

Glover located two painting sites, Lie Siri and Lie Kere, during his survey of the Baucau Plateau (Glover 1972). Like Lene Hara, Lie Siri is a large deep solution cave in a raised coral terrace. Glover $(1972: 157)$ reported a series of positive and negative hand prints in different hues of red in two separate locations deep within the cave. Only two of the prints were well preserved. Glover (1972:157) reasoned that the use of different ochers and the poor condition of some of the prints indicated that they were made at different times. Significantly, he notes that the hand stencils at Lie Siri are at the back of the cave and are only about $1.8 \mathrm{~m}$ above the cave floor (Glover 1972, vol. 2, pl. 5:15 and facing page). 


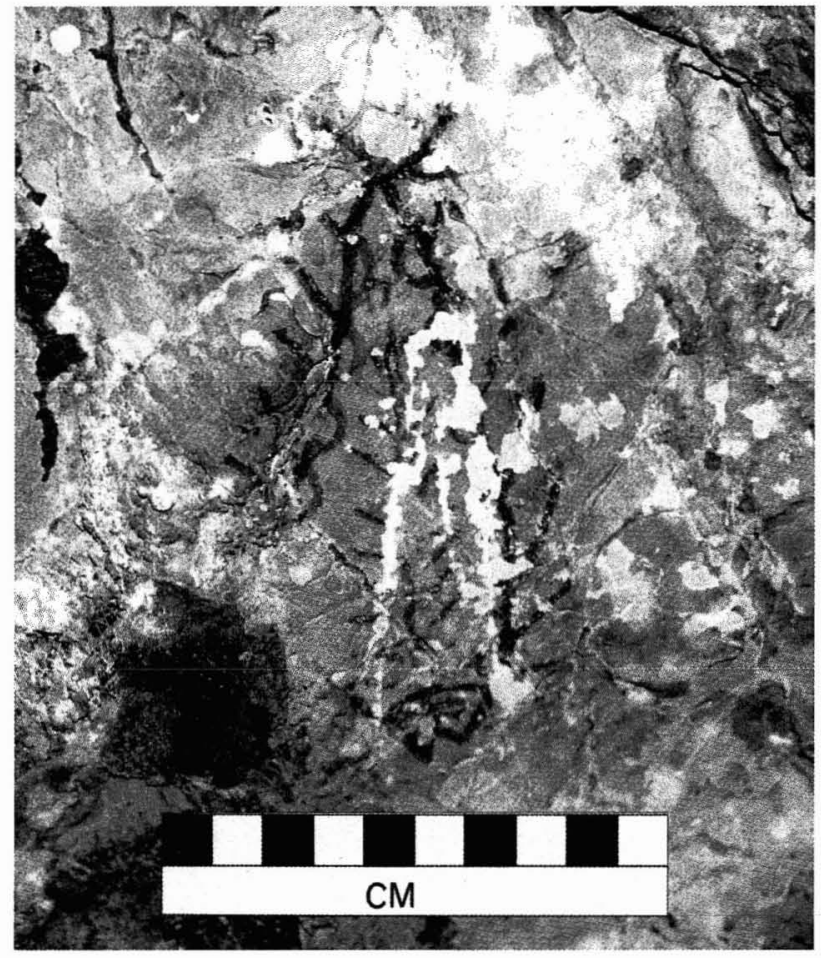

Fig. 6. Lene Hara cave: x-ray fish (red pigment).

Lie Kere is a narrow shelter in a sea cliff on the lowest terrace of the Baucau Plateau, northwest of Baucau. Here Glover (1972:54) recorded four paintings including a "creeper" or "foliage motif" with anthropomorphs beneath (1972, vol. 2, pl. 3:33) (Figs. 8, 9), a "stylized face?" and abstract motif (1972, vol. 2, pl. $3: 34$ ), and an abstract motif with three small crosses above and an anthropomorphic figure beneath (1972, vol. 2, pl. 3:32) (Fig. 10). All are in red pigment. The creeper motif in some areas is covered by reprecipitated carbonate and appears orange-brown. It connects to another yellow and red decorative motif to the east of it that comprises three-cornered crosses (yellow) shown in outline and zigzags (yellow and red), with the red superpositioned over the yellow. The red geometric motif with three small crosses shows deliberate attempts at defacement with deep scratches revealing the white limestone beneath (Fig. 10). This is evident in Glover's original photo. Some black art occurs at Lie Kere, including a lizardanthropomorph figure (Fig. 11). Other lizard-anthropomorphs and anthropomorphs in red were recorded (Fig. 12). Faded red anthropomorphs also occur on the sheer exposed faces of the uplifted coral terrace below the overhang, but these are extremely inaccessible and the artist must have been suspended on ropes or ladders over the cliff edge. At least ten other motifs, many faded or partly obscured by reprecipitated carbonate coatings, were photographed and this site would repay detailed recording.

Glover also visited and made observations at Lene Hara and Ile Kere Kere. At Ile Kere Kere he reported at least 30 paintings, including men on foot, on horseback (Fig. 13) and in boats, as well as a variety of abstract designs. He comments 


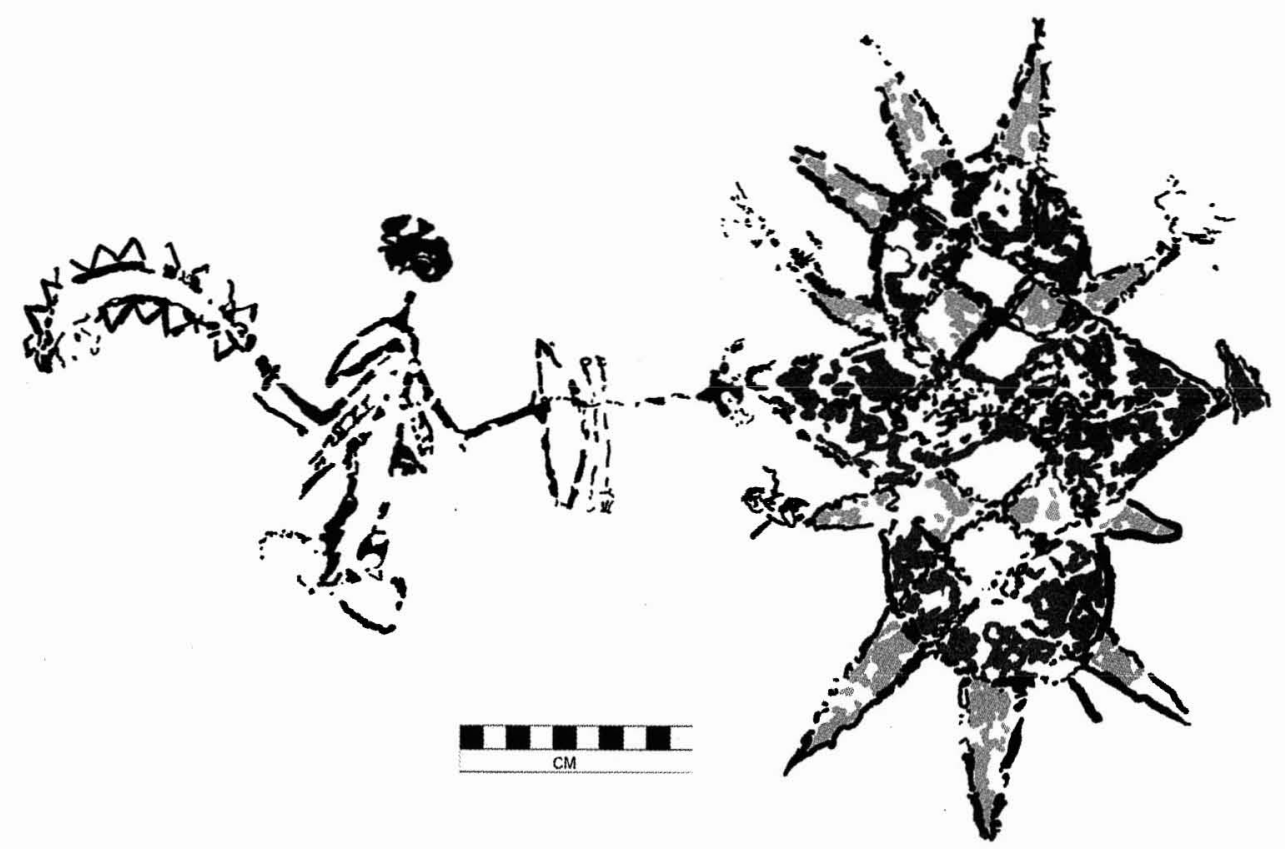

Fig. 7. Lene Hara cave: red anthropomorph holding weapons? (left) and linear design in red, black, and green (right).

that the figures are small, $10-15 \mathrm{~cm}$ high, and mostly in red ocher and notes that "the boat paintings invite comparison with the 'ships of the dead' paintings at Niah (Harrisson 1958:203) and ... in this part of Timor today coffins are regularly made in the form of a boat for the journey of the spirit to its ancestors over the sea" (Glover 1972:42). The date for the introduction of the horse into Timor is not known but when Pigafetta visited the island in 1522 and compiled a list of the products of Timor he made no mention of horses (Glover 1986:11). This omission may indicate that the horse was introduced only with Portuguese settlement later in the sixteenth century.

\section{COMPARATIVE ASSESSMENTS OF THE ROCK ART OF THE WESTERN PACIFIC}

Assessments of the rock art of the western Pacific have been hampered by the limited number of detailed recordings and analysis. In 1979, Jim Specht attempted an overview of the rock art of this region. He defined this region as the area from Seram and Kai in Island Southeast Asia and east as far as Tonga and Samoa. He stated that although nearly 400 painted and engraved localities were known throughout this region, there was insufficient information on design content, location, and composition of the art to undertake stylistic analysis or interpretation (Specht 1979:58, 75). Consequently his review focused on technical and contextual aspects of the art. Almost a decade later Rosenfeld (1988) attempted a synthesis for the same region and could add only one major study undertaken since the time of Specht's review, commenting that rock art research was still a 


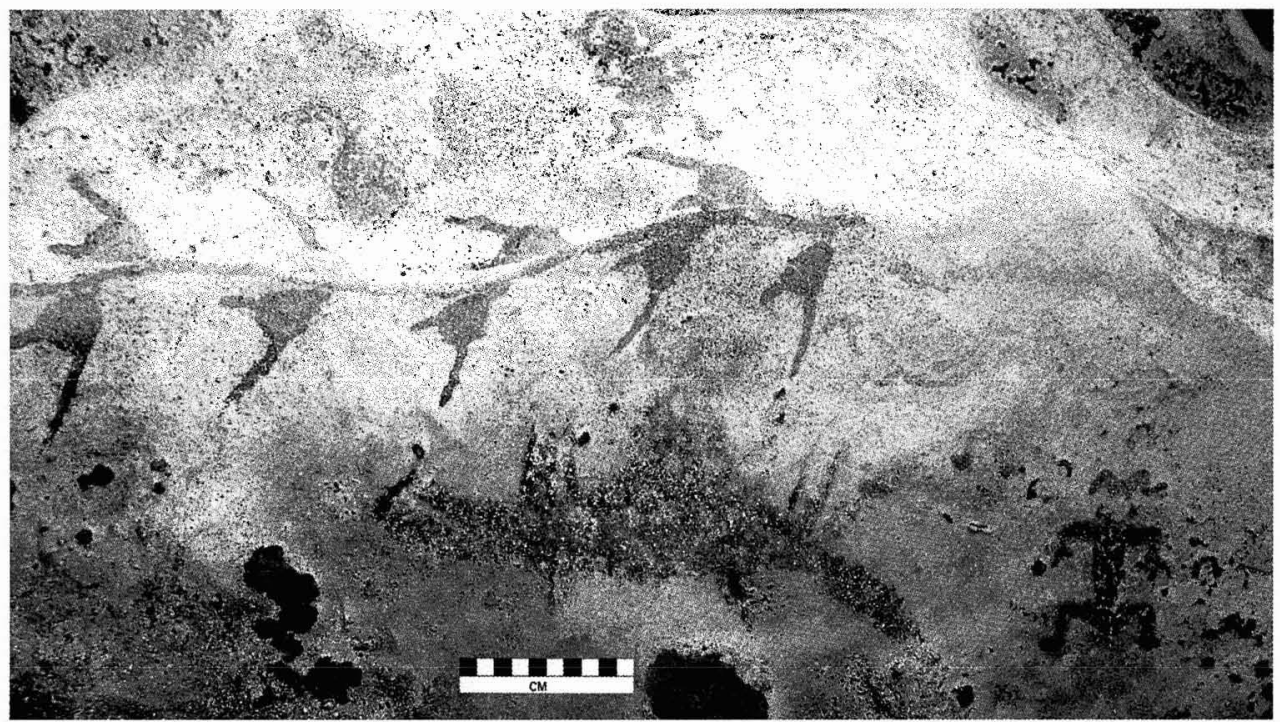

Fig. 8. Lie Kere: foliage design with red anthropomorphs.

serious omission in the prehistory of the Pacific (Rosenfeld 1988:119). Like Specht's synthesis, Rosenfeld's included both engraved and painted sites. Much of her discussion of painted rock art was based on the major study undertaken in the MacCluer Gulf of Papua by Röder almost 50 years earlier (1938-1939). While recent work has been undertaken (for example Wilson's major recording and analysis of Vanuatu rock art, Wilson 2002, n.d.) it is still largely unpublished, and

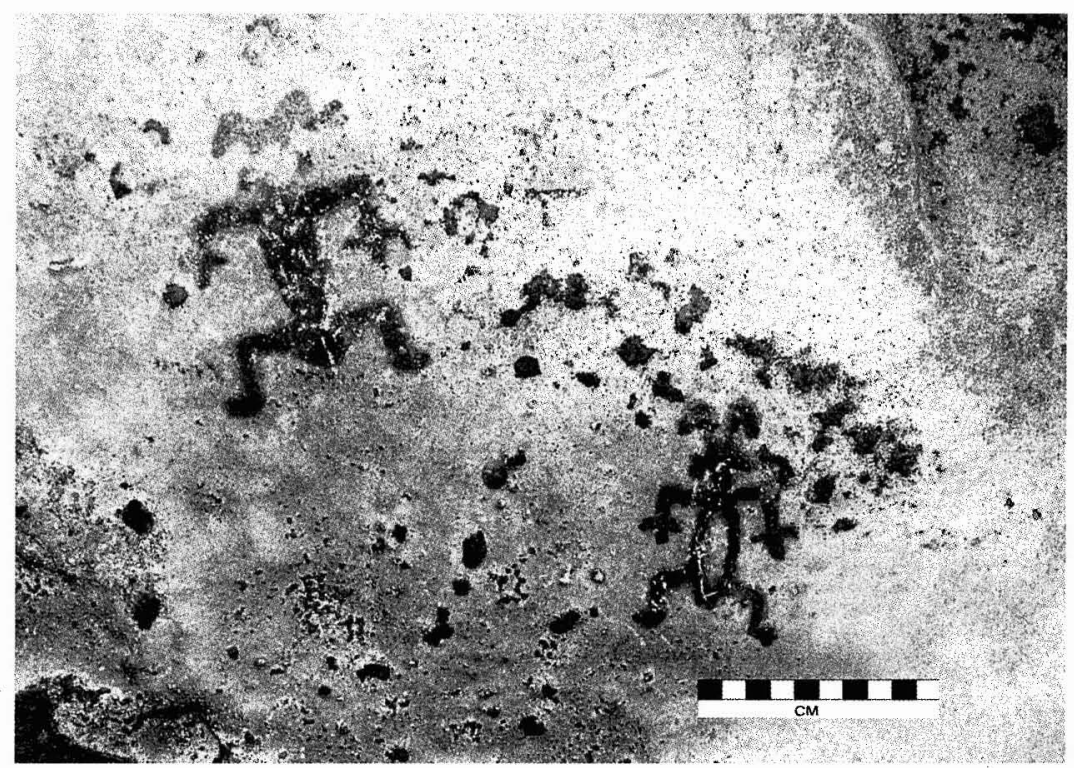

Fig. 9. Lie Kere: detail of red anthropomorphs. 


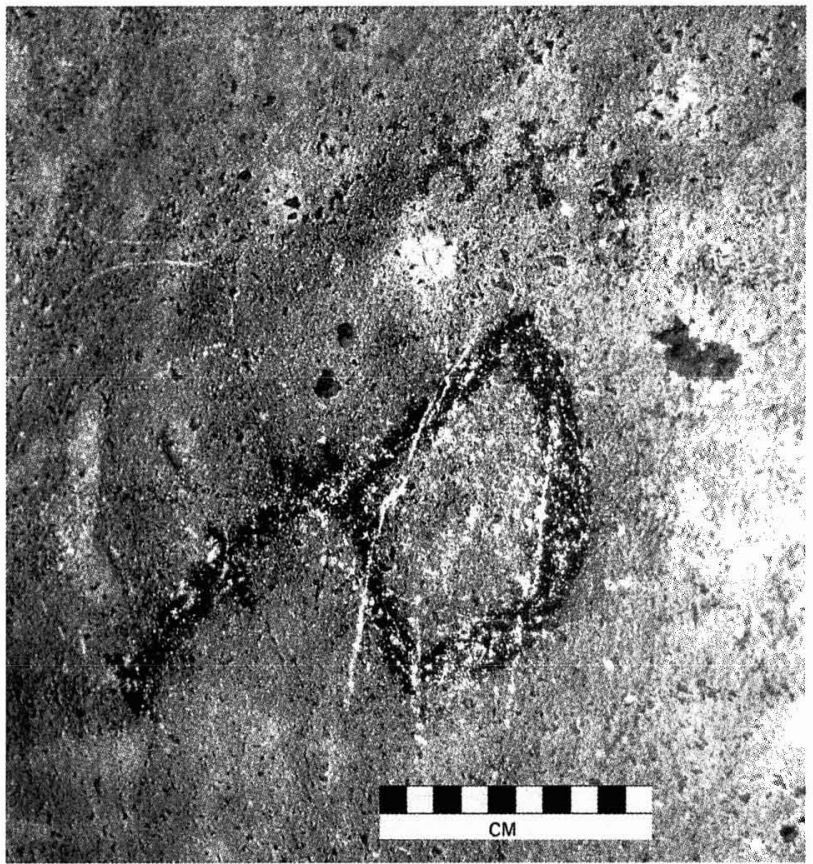

Fig. 10. Lie Kere: defaced abstract geometric in red pigment with three small crosses.

Röder's study remains one of the most comprehensive recordings of a regional body of painted rock art in the western Pacific region. Röder's study and his stylistic schema will be outlined in some detail as it is discussed with reference to the East Timor painting sites below.

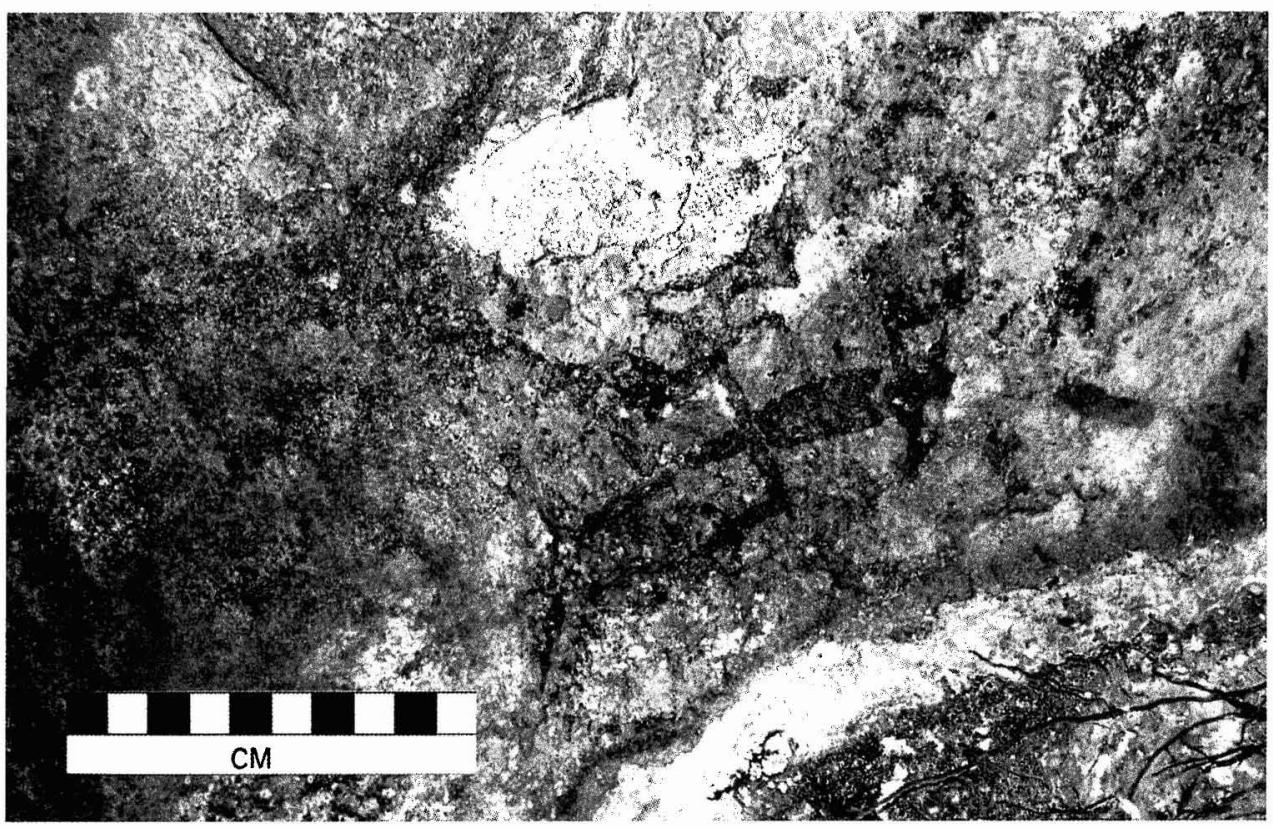

Fig. 11. Lie Kere: black lizard-anthropomorph. 


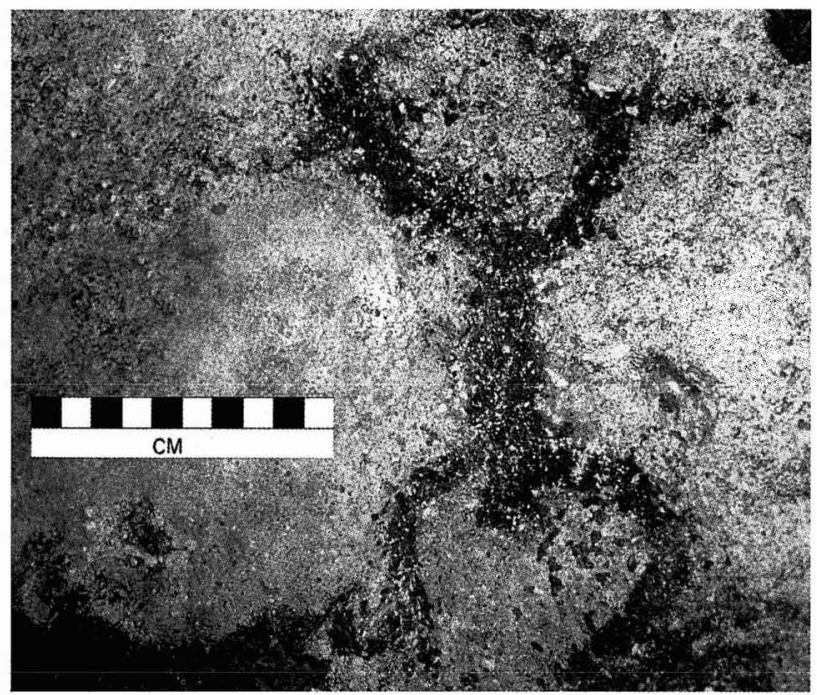

Fig. 12. Lie Kere: red pigment anthropomorph in full frontal pose.

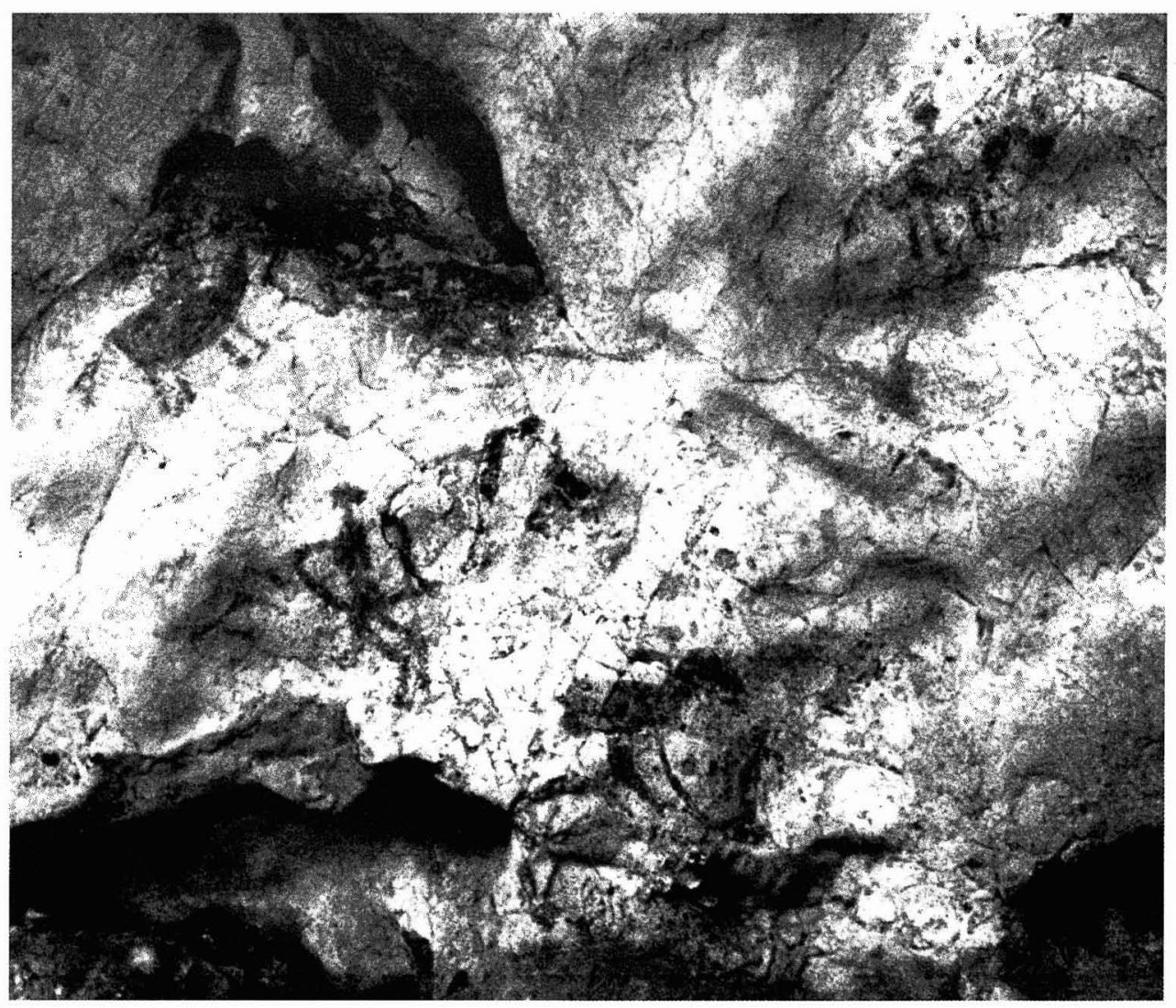

Fig. 13. Ile Kere Kere: red anthropomorphs including figures on horseback. 
The painting sites Röder recorded span a 30-km stretch of the southern coast in shelters and sea cliffs on the mainland and a few small offshore islands. Röder identified several distinct regional "styles" and, on the basis of superposition, he ordered these chronologically. In cases where motifs could not be assigned to one group or another on the basis of superposition, he classified them in terms of color and style. Röder (1956) identified four distinct styles of red painting, the latter two overlapping with black phase painting, and lastly a white painting phase. His earliest red style was called Tabulinetin, after the type-site. It is characterized by stencils, which are predominantly of hands but include feet, a variety of artifacts, and fish. There are also figurative representations of fish and some lizardcrocodile figures and intermediate lizard-crocodile human forms (called Matutuo by Röder). The stencils are often densely overlapped, forming sheets of red pigment, against which the negative and outline images stand out. The figurative paintings of this phase are characterized by a high degree of visual realism and "a fluidity of line that frequently suggests fish in motion" (Rosenfeld 1988:121).

The second phase known as Manga contrasts sharply with the earlier style. It is characterized by elaborate nonfigurative designs in a wide range of forms, many based on circles including concentric circles, circles with rays or spokes, and more complex symmetrical structured patterns and interlocking scrolls or what Röder calls "spiral labyrinths." "The clear-cut linear structure of even the most complicated symbolic signs is one of the strong points of the Manga style" (Röder 1956:394).

Importantly, during the Manga phase individual motifs usually appear in isolation. The figures are controlled and precise although they lack the compositional unity found in the Tabulinetin. Stencils cease to be a prominent part of design. Fish motifs persist but they are less representational, with the inner organs or skeleton indicated occasionally. Lizard-human forms also continue into this period. Red pigment tones in Tabulinetin and Manga range from vermilion, blood red, and purplish brown to yellow, but Röder doesn't believe these color variations have chronological or stylistic significance (1956:393).

The Ota and Arguni styles follow the Manga and retain some of its elements. Ota contains a similar range of linear designs but they tend to be larger and less carefully executed. Some writers, including Röder himself (1956:399), saw both Ota and Arguni as a degeneration of the earlier styles (Berger-Kirchner 1970:234). Arguni consists mainly of simple geometrics and other abstract motifs. Stylized ships figure prominently for the first time in these later phases and Röder (1956:399) comments that many of the images reproduce "Moluccan boat types." The Arguni and Ota are thought to parallel or overlap the earliest black paintings since similar boats and geometric motifs appear in both red and black pigment, and sometimes black and red are combined in one picture (Röder 1956:399). Except when black and red are used in the same motif, black always overlies red. Röder reports that the painted caves house many burials, some of which are interred in boat-shaped coffins. Local informants told him that the coffins "represent boats in which the deceased is supposed to reach the beyond." Röder believed that the boat coffin burials were contemporaneous with the Ota as black drawings from this phase were similar to those found on pots in the burials (1956:388). Röder (1959) identified changes in techniques, which coincided with the stylistic phases. The earliest, Tabulinetin, relied on stenciling 
and wet delineation, the red paintings in Manga, Ota, and Arguni on wet delineation, and the black drawings, dry delineation.

Neither Specht (1979) nor Rosenfeld (1988) believed that Röder's schema could be readily extrapolated to the broader region. Rosenfeld (1988:134) emphasized instead the "great diversity of localised artistic expression" within the region. She saw two distinct traditions represented by the engraved images and paintings with little overlap, although she allowed that some motifs of possible Dong Son origin found in both perhaps suggest "differential adoption and adaptation from shared origins" (Rosenfeld 1988:134). Circles, spirals-scrolls, and the use of spirals to construct the "scissor-shaped" motifs (inversion of the "heartshaped" scrolls) were, she believed, more characteristic of the engraving tradition (Rosenfeld 1988:134).

In the same publication, Ballard (1988) described and illustrated the rock art of the Dudumahan sea-cliff shelters on the island of Kai Kecil, southeast Moluccu. Ballard described a range of motifs (over 300 ) of which the majority ( 84 percent) are painted freehand and the remainder (16 percent) are stencils. The predominant color used is red. The dominant figurative designs are small anthropomorphs portrayed holding weapons or tools and Ballard compares them to the small active figures at Ile Kere Kere (Ballard 1988:151). Stylized boats are also prominent. Common nonfigurative designs are based on variations of the rayed or barbed circle. Other geometrics include zigzags and crosshatched motifs. Ballard (1988:154) concludes that, "there is little correlation between motif and color variation at Dudumahan... While a rough sequence of black over red over light orange and yellow can be inferred, the lack of correlation with variation in motif suggests that the sequence may have little chronological depth or significance."

In 1992, Ballard extended his assessment to include the entire corpus of 187 painted sites then known from the area he called Western Melanesia. He defined this area as "Papua New Guinea including Buka and Bougainville Islands, together with the eastern Indonesian provinces of Irian Jaya, Maluku, Timor Timur and Timor Barat." He therefore included the six known painted rock art sites of East Timor.

The variables he used to assess the paintings were predominantly topographic and geographic. They were:

1. Distance of the site from the nearest current coastline.

2. Topographic or physical context of the sites using the categories:

a. Cliff faces only.

b. Caves and, or within, cliff faces.

c. Caves set in uplifted coral terraces.

d. Caves or rockshelters only.

e. Boulders.

3. Maximum height in meters of the location of the art in each site. This was taken as the height from which the artists must have raised themselves to execute the paintings and gives an index of relative inaccessibility.

4. Language group. He distinguishes between areas where Austronesian (AN) or non-Austronesian (NAN) languages are currently spoken.

The results of Ballard's (1992:98) survey suggested that there was "a class of painted rock art sites within western Melanesia, found in inaccessible but highly visible locations, most commonly sea-cliffs" (a feature previously noted by Specht 
1979:65). In general, these painting sites show a high co-occurrence with Austronesian-speaking settlements, leading Ballard to propose that this class of art "postdates the spread of Austronesian speaking communities" c. 4000 years ago and may "constitute elements of a single symbolic tradition of cultural and historical significance” (Ballard 1992:98). Like Rosenfeld, Ballard reasoned that motifs shared by the art and some Metal Age artifacts, such as Dong Son drums, suggested an age closer to 2000 B.P.

Although little formal analysis of the rock art had been carried out, Ballard believed that it was possible to identify "a unity in the painted art" of this region, which encompassed "the use of specific techniques, colors and motifs across many of the sites" (Ballard 1992:98) with the addition of regionally specific figurative components.

Ballard concluded that the painted rock art of East Timor fits within this broad definition of the Austronesian painting tradition. Certainly, several of the known sites met the geographic criteria outlined above. On linguistic grounds, however, the East Timor sites were more difficult to reconcile with the model. Ballard placed five of the six known sites, Tutuala Scarp, Ile Kere Kere, Lene Hara Cave, Sunu Taraleu Scarp, and Lie Kere in NAN language areas. Ballard in fact wrongly ascribed Lie Kere to a NAN area. It falls within an AN language area. Even so, this still puts four of the six sites in NAN language areas. Ballard reasoned that this might be due to movement of NAN language speakers into these areas in the recent past and as discussed below, it would seem that he may well be correct.

\section{THE NINE NEW PAINTED ROCK ART SITES IN EAST TIMOR}

Figure 1 shows the location of the known and newly identified art sites and the distribution of language groups within East Timor today.

\section{Lie Baai}

This extensive overhang on the Baucau Plateau is within the coral terrace at a height of approximately $360 \mathrm{~m}$ in altitude and faces directly north to the sea, about $1 \mathrm{~km}$ distant. The overhang is $70 \mathrm{~m}$ long, $25 \mathrm{~m}$ deep, and $20 \mathrm{~m}$ high. The shelter is still used periodically by families visiting their gardens and has a hunting hide constructed from coconut fronds at the east end and a stone and brush fence along the front. Broken pottery and marine shell are scattered on the surface of the deposit. At the western end are drawings in dry charcoal that locals identified as belonging to the period of resistance of the past 25 years. In this area of the overhang, there appear to be red and black figurative forms, which are veiled by reprecipitated carbonate coatings. This site would probably benefit from enhanced digital recording.

\section{Lie Kere 2 (East Timor Site 43)}

This overhang on the Baucau Plateau has the same name as the painting site previously recorded by Glover and described above, so has been identified as Lie Kere 2. Local Austronesian speakers translate kere as 'marking,' 'writing,' or 'drawing,' This site is located in a coral terrace at an altitude of $130 \mathrm{~m}$ and faces 


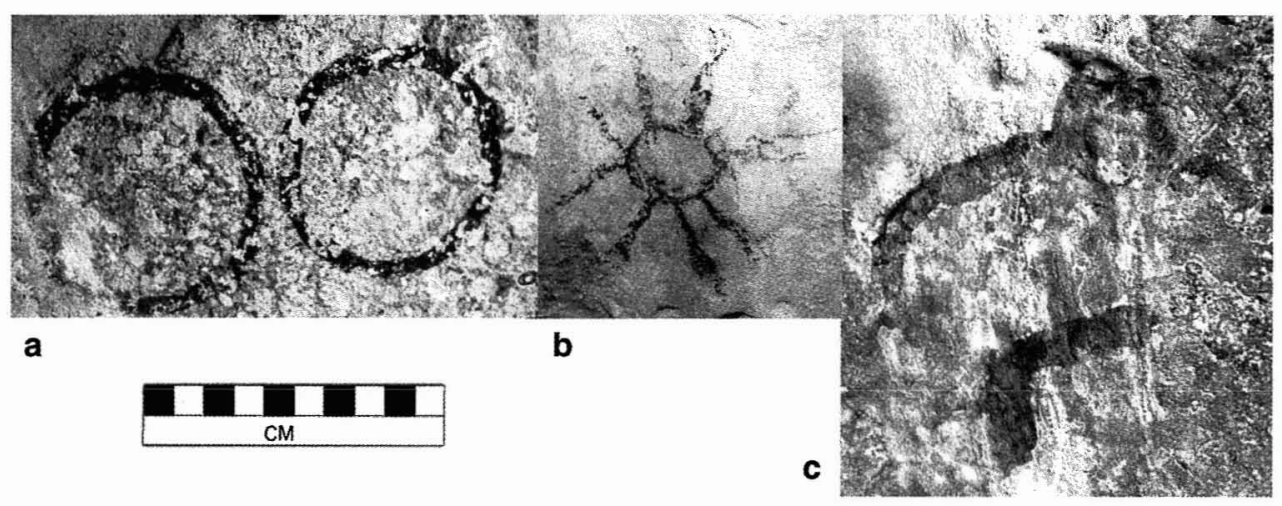

Fig. 14. Lie Kere 2: three separate geometric motifs: a: red circles; b: black, dry application rayed circle-sun; c: black, wet application figure.

northeast to the sea, which is less than $20 \mathrm{~m}$ from the shelter entrance. The floor of the deposit is very rocky and it appears that exfoliation is fairly rapid in this exposed environment. Little sediment is deposited but marine shell and pottery sherds were abundant on the rocky surface. The walls of the overhang have faded simple red and black geometric motifs, including simple circles in red pigment (Fig. 14a), a radiating circle/sun in dry black pigment (Fig. 14b), and indeterminate figurative motifs in wet black pigment (Fig. 14c). No cases of superposition of color were noted. Even the few remaining motifs are weathering rapidly and it is apparent from the areas of red "wash" with bare suggestions of form that art was previously more abundant. Some motifs, such as the interconnected open and infilled triangles in Figure 15b, show signs of deliberate defacement, like those at Glover's Lie Kere. All the design elements at Lie Kere 2 occur in other painted rock art sites in the western Pacific.

\section{Vérulu}

The site of Vérulu is on the north coast, northwest of the village of Mehara. It easily meets the topographic and geographic criteria of Ballard's model. The art faces due north to the sea, on the face of an overhang which is formed by two huge boulders in the raised coral terrace (Fig. 16). The two boulders are separated by a small gully. They are approximately $1 \mathrm{~km}$ from the coast and approximately $500 \mathrm{~m}$ above sea level. Due to the elevation, the site has panoramic 180-degree views to the coast. A few sherds of plain pottery, sparse shellfish, and some fragments of coconut spoons as well as small quantities of burned and unburned bone are exposed on the surface of the site. Numerous pegs have been inserted into natural cavities in the walls of the overhang from which bags or other objects can be hung.

The motifs in the Vérulu site include a large red anthropomorph with exaggerated leg muscles and elaborate headdress (Fig. 17, upper right), a series of geometric latticing in faded red or yellow, and a number of small red-yellow anthropomorphs (Fig. 17, left of panel). The western chamber has a series of boats in black (Fig. 18). 
a
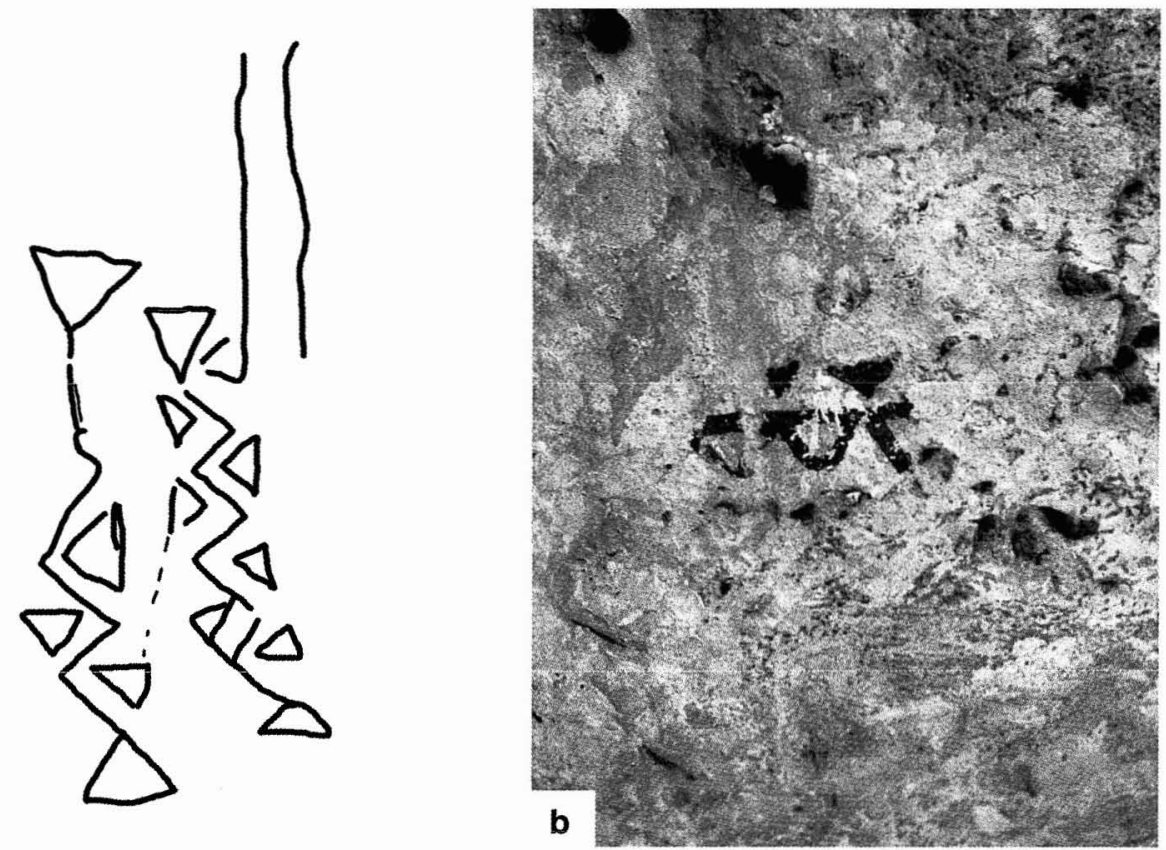

Fig. 15. a: Drawing by the artist Hahn after motif in the MacCluer Gulf (color of original unknown) (Röder 1959:156, pl. 20); b: Lie Kere 2 interconnected triangular pattern (red pigment).

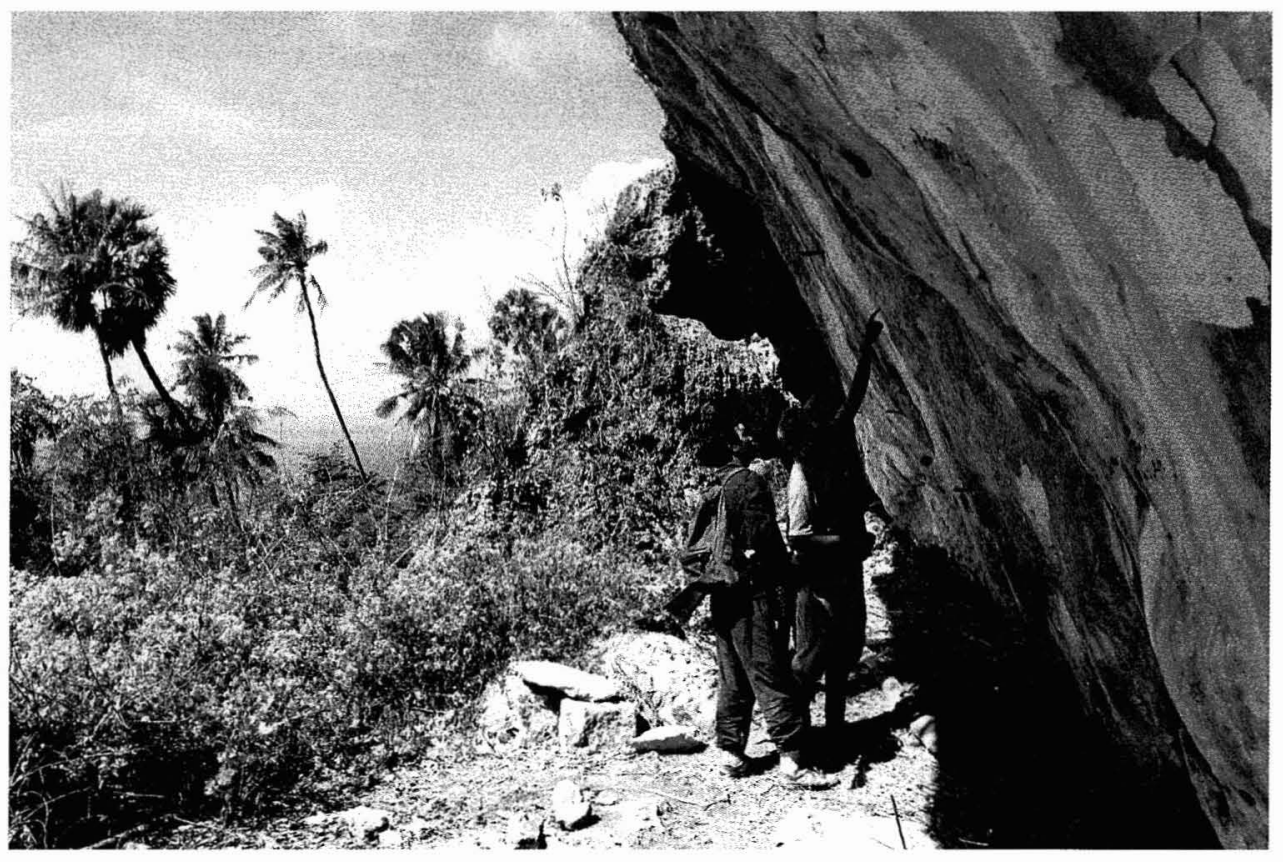

Fig. 16. Vérulu shelter. 


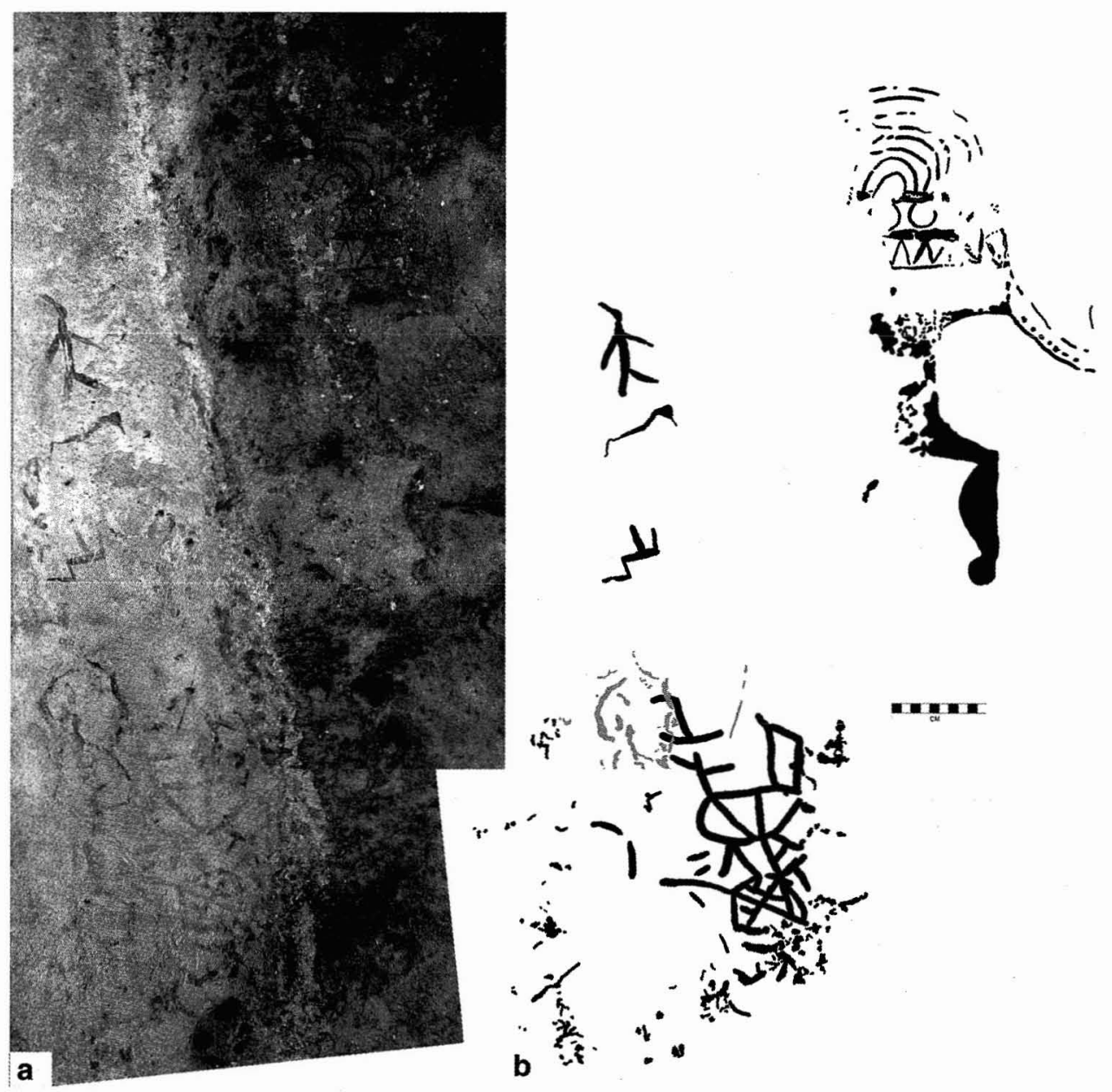

Fig. 17. Vérulu shelter: large red anthropomorph with exaggerated leg muscle (upper right) and small anthropomorphs and latticing (left).

The most prominent figure in the panel, the red anthropomorph, is much larger than anthropomorphic figures previously recorded in the sites of Ile Kere Kere and other recorded art of East Timor. It is portrayed in full frontal pose and is shown with either an elaborate head decoration or carrying an elaborately decorated object on its head. Only half of the figure remains; the easternmost side (facing) has been removed. The lower limbs are shown with accentuated muscle definition. The head cannot be seen and, if part of the original design, must have been very small. The figure is approximately $50 \mathrm{~cm}$ in height from the feet to the top of the headdress. This figure is very similar to anthropomorphs with exaggerated leg muscles found in the petroglyphs of Hawai'i and often referred to as "birdman figures" (Lee and Stasack 1999: xii, fig. 1.2., 152, fig. 10.7). Crescentic bands emanating from the head of some of these figures are usually interpreted as headdresses. The Hawaiian figures are often over $100 \mathrm{~cm}$ in height (Lee and 

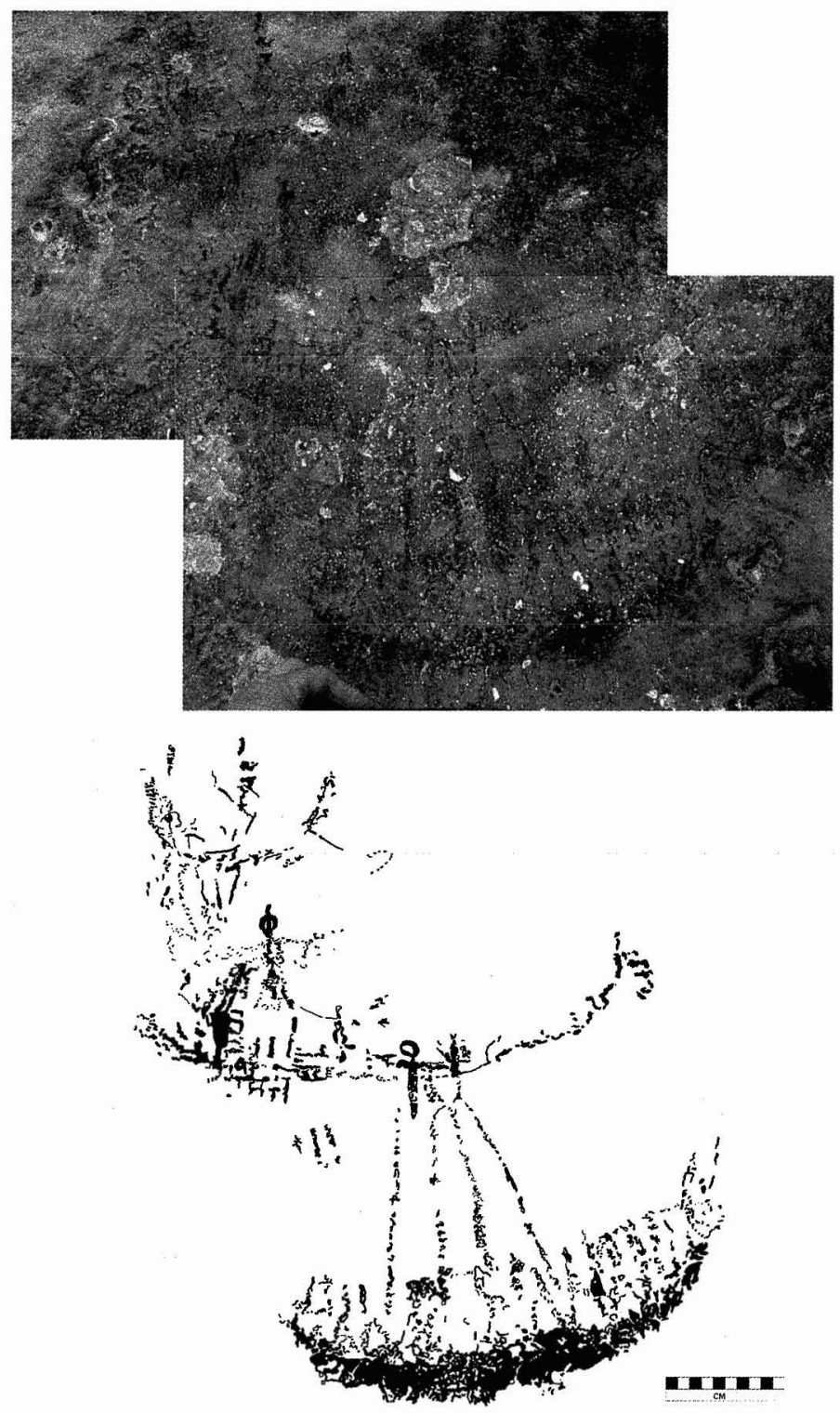

Fig. 18. Vérulu shelter: panel of dry drawn black boats and anthropomorphs, some highly schematized.

Stasack 1999:74). The arm muscles are also usually exaggerated and extend out from the shoulders, hence the name "Birdman," however, occasionally the arms are not muscled and are shown extending above the head (Lee and Stasack 1999:122, fig 8.34). On some of the more stylized of the Hawaiian figures, the head is barely represented and on most it is shown as significantly smaller than a proportional representation would have it appear. 
The anthropomorphic figure at Vérulu is positioned at a height of $2.2 \mathrm{~m}$ above the floor of the shelter. It is likely that some form of construction must have been erected to execute it.

Vérulu has motifs in red, yellow, and black pigment and, where superposition is evident, it is black over yellow or black over red. No instances of red-yellow or yellow-red superposition were recorded. In fact, the gradation of color in the latticed pattern indicates that the yellow here may in fact be the result of the red pigment weathering. In short, there is little correlation between motif and color variation although there is a stronger relationship between style and color. Boats and anthropomorphs in the western chamber are more sketchily executed than the red art. Often a mere suggestion of a feature is shown. These images have been drawn dry onto the limestone surface.

\section{Lene Cécé}

Lene Cécé is a small cliff face shelter with a panel of spectacular red painted motifs, most prominent of which is the large boat shown in Figure 2. The overhang is approximately $2.5 \mathrm{~km}$ from the village of Tutuala, off the road to Valu Beach and at about $250 \mathrm{~m}$ altitude. It is approximately $500 \mathrm{~m}$ northeast of the road and faces southwest. Unlike the scarp sites recorded by Almeida, Lene Cécé is not coastal facing and is several kilometers from the sea. The dominant motifs here are small, active anthropomorphs in frontal and profile positions, boats, and rayed circle/sun motifs. The large boat has a high, swept up prow, which is elaborately decorated and is shown in x-ray with human figures on deck and within the boat (Fig. 2). Some of the figures have elaborate headdresses and are holding weapons or other objects. Above the boat is a bird that appears to be connected to one of the human figures by a line or rope. This bird bears a close resemblance to a cassowary. A rayed circle/sun motif above the boat has 12 solid red rays and the central circle is divided into quadrants. The paintings are placed high on the wall of the overhang, the highest over $3 \mathrm{~m}$ from the floor, and a ladder had to be constructed in order to photograph them.

Lene Kici 1-Lene Kici 1, 2, 4, 5, and 6 are all within the Tutuala region near the north-northeast coast. Lene Kici 1 is a tunnel cave in a coral terrace at about $100 \mathrm{~m}$ in altitude, approximately $2 \mathrm{~km}$ northeast of the village of Tutuala. The terrace is low and the cave entrances are well hidden behind secondary forest. The Falantil used this cave during the past 25 years to hide from the Indonesians and, most recently, in 1999, it was used by families in the Tutuala region to hide from the militia. The cave has a sparse scattering of marine shell on the surface but little or no deposit. The paintings are in two separate and discrete areas of Lene Kici 1 (Fig. 19). The best prẹserved and most prominent of the Lene Kici 1 paintings is on a panel, above a high narrow ledge, at the front of the cave. The panel faces north-northeast to the coast and can only be accessed by climbing. The image is of a red canoe with a central staging. It has a high, decorated prow and stern with a steering oar. Four human figures, also in red, are shown within the canoe (Fig. 20). Well inside the cave entrance are other less well-preserved red motifs including some faded geometrics, two hand stencils, and the tail of a fish in solid red pigment. The remainder of the fish is missing, probably removed by water. 


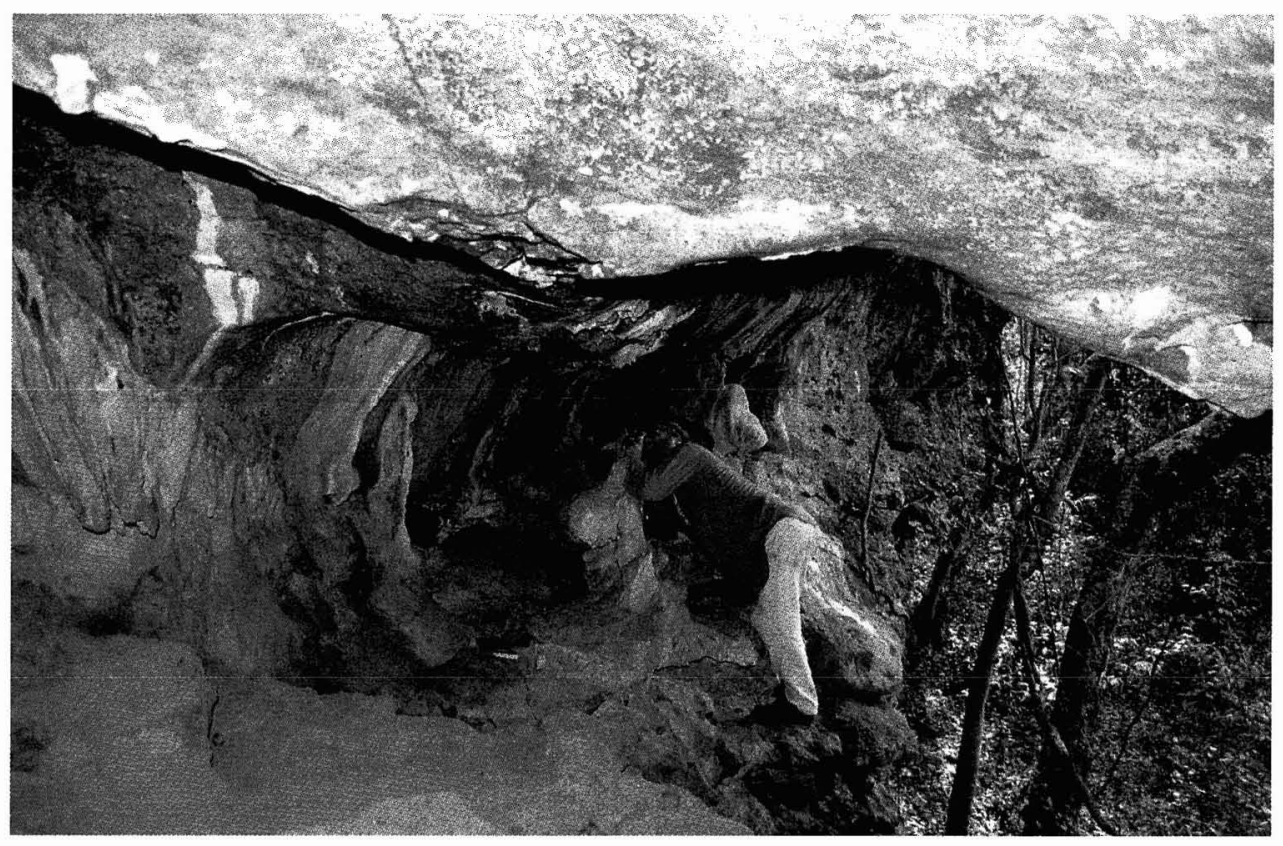

Fig. 19. Lene Kici 1: Matthew Spriggs photographing boat painting above high narrow ledge, at entrance to cave.

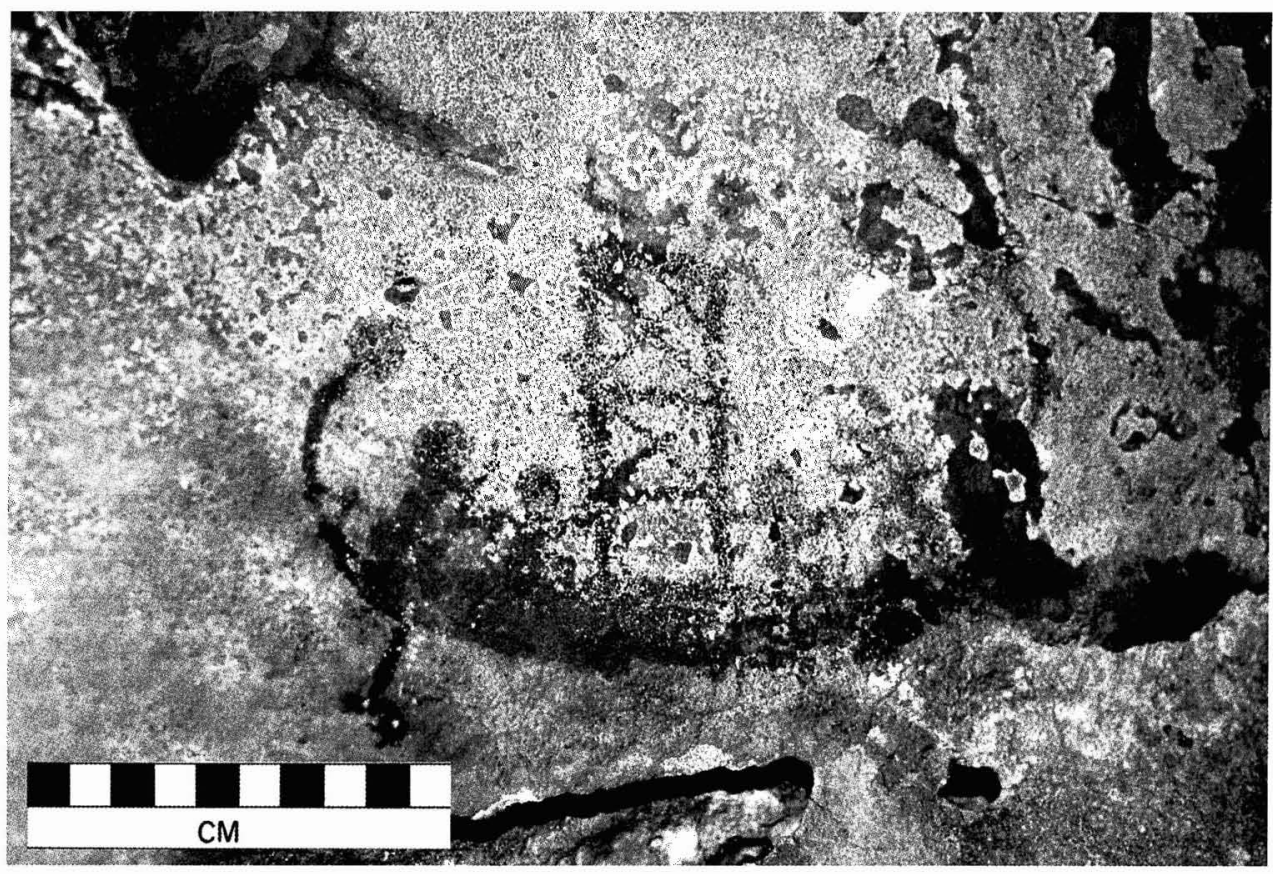

Fig. 20. Lene Kici 1: red pigment boat with central staging. 

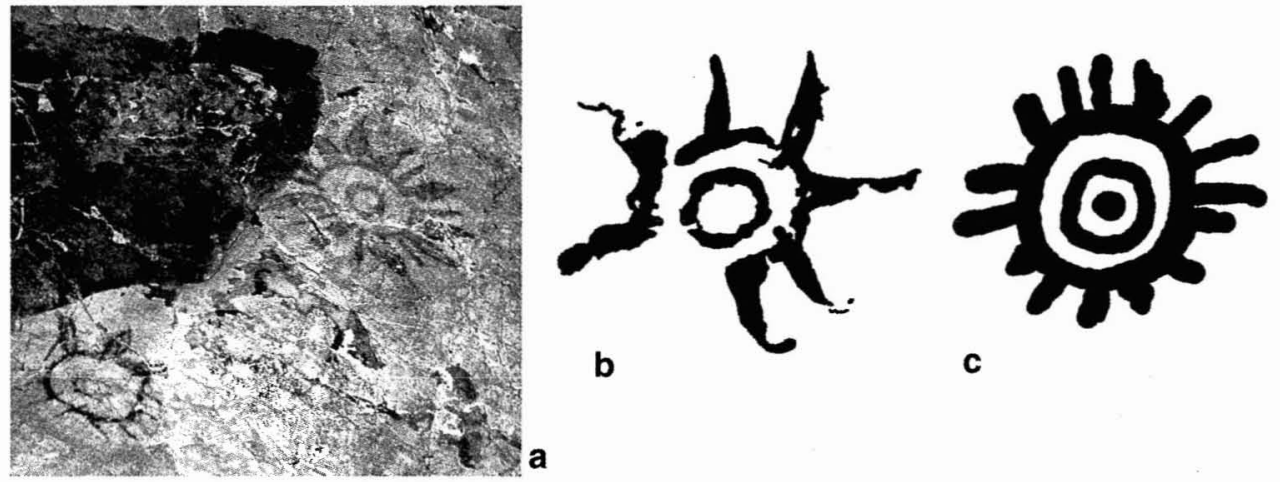

Fig. 21. Variations on rayed or barred circle-sun motifs: a: Lene Hara (red pigment); b: Lene Kici 2 (red pigment); c: MacCluer Gulf (red pigment) (Röder 1959:109, pl. 36).

Lene Kici 2-Approximately $50 \mathrm{~m}$ northeast of Lene Kici 1 is another tunnel cave in the same ridge formation, Lene Kici 2. Two rayed circle-suns in red (Fig. 21b) and several black motifs, possibly very simple stylized boats (Fig. 22a), overlie indecipherable faded red pigment. Highly schematized or abstracted boats are common in the MacCluer Gulf (Fig. $22 b-e$ ) and were recorded by Ballard at Dudumahan (1988:153, 6xi, 41, 2vi). They are also found in other sites in East Timor such as Vérulu (see, for example, Fig. $22 f$ ). The red-rayed circle-suns are similar to those at Lene Hara (Fig. 21a) and in the MacCluer Gulf (see Röder 1956:109, pl. 36) (Fig. 21c) and to the multiple variations on this motif found at Dudumahan (see Ballard 1988). Variations on rayed circles are also seen on painted pottery found on the surface at Niki Niki in West Timor (Glover 1972, vol. 2, pl. 9:2a). Lene Kici 2 has some depositional depth and evidence of recent occupation. A nearly complete cooking pot was abandoned on the surface. Our guide Meccario told us that this cave had been used by people from Tutuala to hide from the militia.

Lene Kici 4-Lene Kici 4 is a tunnel cave about 20 m west of Lene Kici 1 . The cave is approximately $7 \mathrm{~m}$ deep and $4 \mathrm{~m}$ across. This art is positioned approximately $1.5 \mathrm{~m}$ above the current ground surface and $3.5 \mathrm{~m}$ inside the cave entrance. A solid red anthropomorph and other indeterminate red figures are both faded and covered with an accretion of reprecipitated carbonate. The anthropomorph is headless and appears to be holding an object in its right hand.

Lene Kici 5-Lene Kici 5 is a very large tunnel cave approximately $25 \mathrm{~m}$ west of Lene Kici 4. Although it is approximately $30 \mathrm{~m}$ deep and $15 \mathrm{~m}$ wide, some light penetrates to the back of the cave. At least two red hand stencils and some other indeterminate faded motifs in red are approximately $1.5 \mathrm{~m}$ above the deposit surface and $7 \mathrm{~m}$ inside the cave mouth. The site has some deposit and marine shell was seen on the surface. A large clam was placed against the wall of the cave to catch droplets of water coming off the ceiling.

Lene Kici 6-Just to the right of Lene Kici 5 is a smaller tunnel cave, Lene Kici 6, which contained at least one red hand stencil and some other faded indeterminate red markings. Here again the stencil and red paintings were well within the deep chamber of the cave. 

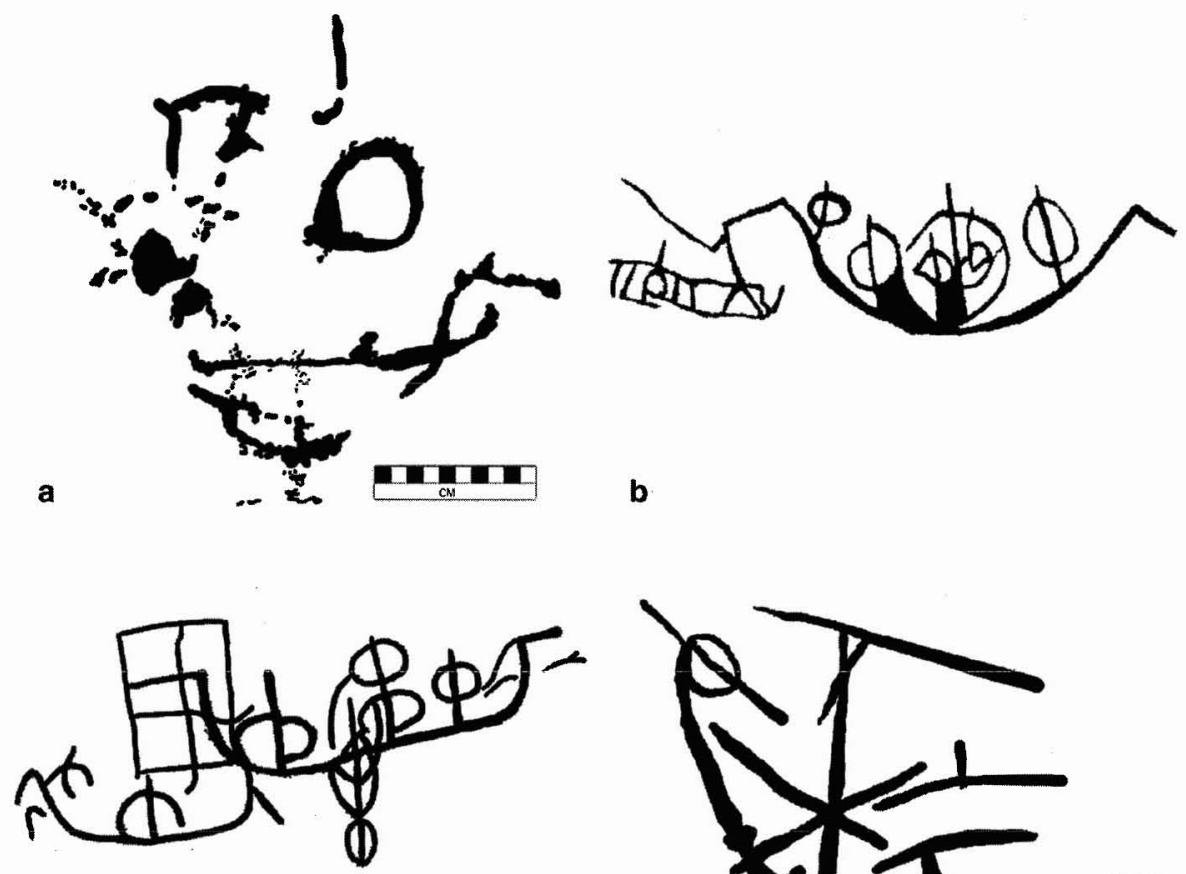

c

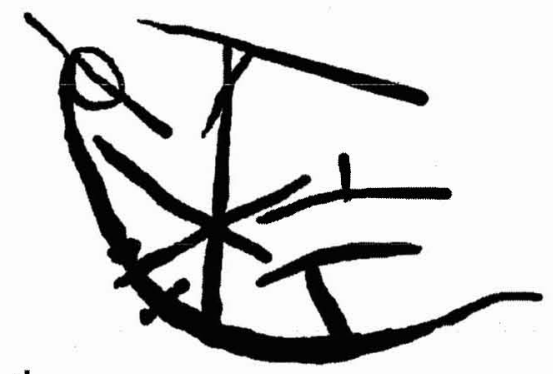

d

b

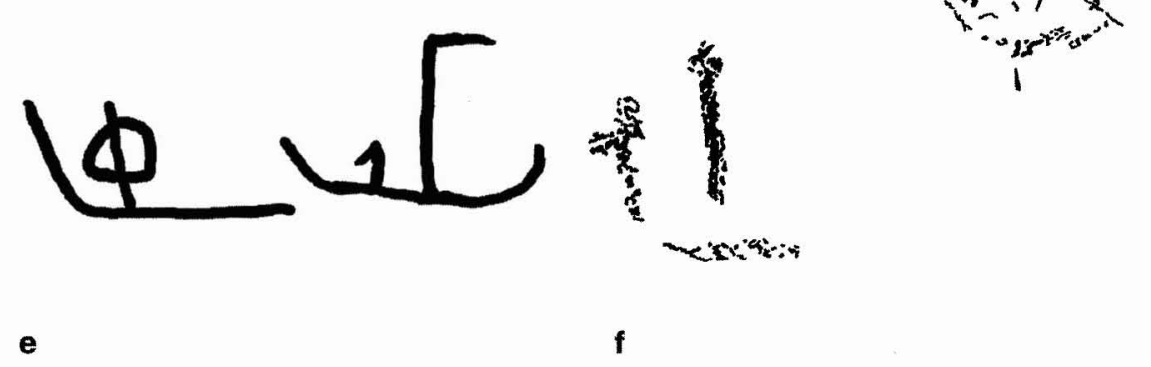

Fig. 22. Schematized boats: a: Lene Kici 1; b: MacCluer Gulf (Röder 1959:155, pl. 5); c: Röder 1959: 155, pl. 2); d: Röder 1959: 139; e: Röder 1959: 155, pl. 9; f: Vérulu (black pigment).

\section{EAST TIMOR PAINTING SITES IN THE CONTEXT OF THE WESTERN PACIFIC}

Assessment of the East Timor painting sites indicates that they share many features with other painted sites in the broader western Pacific region, supporting Ballard's claim for the inclusion of East Timor sites within the "Austronesian painting tradition." In fact, a case can be made that there are stronger affinities between motifs separated by great geographical distance and a lot of water than there are between representational motifs between and within the East Timor sites. However, there are also other features which distinguish the corpus of East Timor art 
from that of the region. Some of the features that both distinguish the East Timor art, and ally it with other bodies of Austronesian painted art, are discussed below.

\section{Geographic and Topographic Variables}

While many of the painting sites are in exposed cliff faces and the paintings within them are often positioned in inaccessible areas (thereby meeting Ballard's topographic criteria), some sites are located inland some distance from, and out of sight of the sea. These sites are deep solution caves in the limestone terraces with interior walls, which go back many tens of meters. Some of these caves contain "deep art" positioned in accessible locations on the walls within the cave. The motifs positioned within the caves appear distinctive, or "separate" from those on the external or exposed faces and the choice of location a deliberate one, as exposed panels are available on external surfaces/faces of the caves with "deep" art, and in some cases, such as at Lene Kici 1, these are also painted. The deep art seems to encompass hand stencils, a partial fish, a single anthropomorph, and nonfigurative geometrics and is always in red pigment. Aside from the stencils and geometrics these red figures are always in solid pigment, rather than outline. This art is not positioned high on the walls and could have been executed without constructing scaffolding or supports of any sort. The images are often faded or obscured by carbonate accretions. This inside or deep art is found at Lie Siri, Lene Hara, and Lene Kici 1, and Lene Kici 4, 5, and 6. Hand stencils are rare in the exposed cliff-face sites in East Timor, contrasting with the MacCluer Gulf and Kai Kecil sites. Conversely, boats of any sort and small "active" anthropomorphs appear exclusively in exposed positions. Some of the paintings at Lene Hara do not fit easily into either group.

The dualism seen in the placement of art in East Timor may be a function of chronology. Alternatively, if synchronous, the art may reflect different functions, such as personal or individual marking of place/space (inside and accessible) versus group/corporate identification or signaling. (external inaccessible) (see Rosenfeld 1997 for discussion of how different systems may operate simultaneously for different purposes).

\section{Linguistic Distribution}

Superficially, the distribution of the East Timor sites is difficult to reconcile with Ballard's model for the co-occurrence of painting sites with AN-speaking areas. Of the six previously recorded sites in East Timor that Ballard reviewed, four are in NAN-language areas. Of the nine new sites located between 2000 and 2001, seven are in NAN-speaking areas. However as noted above, when Almeida visited the Tutuala region, he was told that the area had previously been occupied by Makua speakers. Today only a handful of Makua speakers remain, all of whom live in the village of Mehara, west of Tutuala. In the past there was some debate regarding whether or not Makua was an Austronesian language. Recent linguistic work has confirmed its status as an Austronesian language, albeit an unusual one (Hajek and Himmlemann 2001). It would appear therefore that the Tutuala region was previously occupied by AN-language speakers and that the movement of NAN speakers into this region occurred in historic times. 

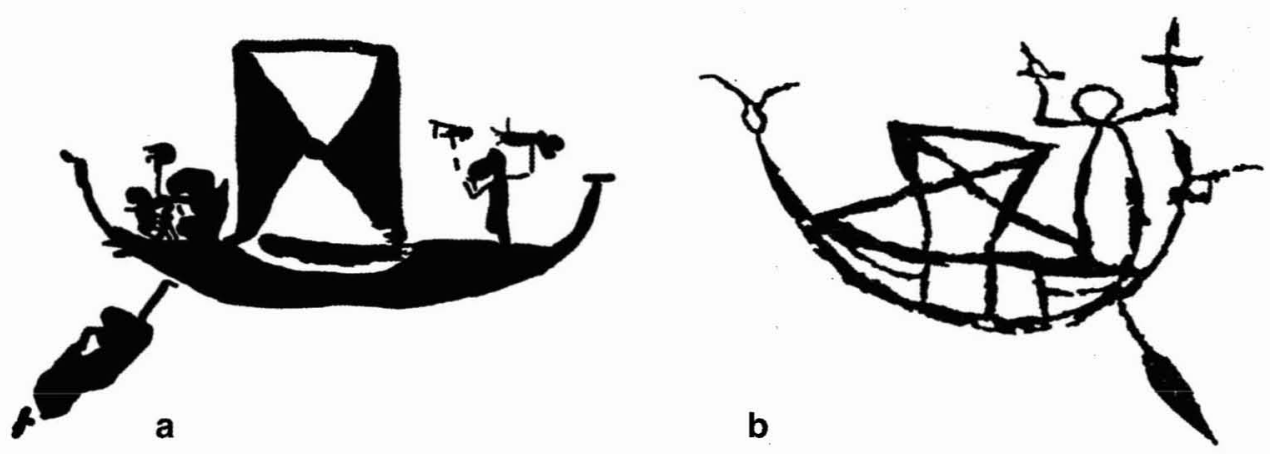

Fig. 23. a: Boat from Lene Cécé; b: boat from the Dudumahan site at Kai Kecil, both in red pigment.

\section{Design Elements, Motif, and Composition}

Hand stencils occur in the East Timor sites but they are not abundant, and as noted above are most often found on the internal walls of deep solution caves, rather than in exposed inaccessible positions on sea cliffs such as at Dudumahan in the Kai Islands and in the MacCluer Gulf.

Most common figurative motifs in all sites are small active anthropomorphic figures, and, as at Dudumahan, these are often depicted holding weapons, tools, or indeterminate objects. There is a huge diversity of forms and features among the anthropomorphs. Some, such as the Ile Kere Kere figures, are shown in profile, often with raised arms. Others, such as the small figures in the lattice panel at Vérulu, are mere stick figures providing no more than a suggestion of the human form and action. The small upper figure appears to be shown in profile whereas the bottom figure, with only the legs remaining, is shown in frontal pose with legs splayed from the torso and bent.

The anthropomorph at Lene Hara with the complex linear decoration in place of a head (Fig. 4) has x-ray feet, identified as a distinctive feature of some of the anthropomorphs at Dudumahan (Ballard 1988:151, fig. 7, 3i, 1vii, 2iii-v) and which Ballard (1988:150) notes as a shared feature with the MacCluer Gulf anthropomorphs. Ballard also draws attention to some shared features between the active red anthropomorphs at Dudumahan and those at Ile Kere Kere (Ballard 1988:150-151).

The large anthropomorph with complex head decoration and exaggerated muscles at Vérulu is unlike any other anthropomorph, either in terms of size or style, seen in East Timor sites or those at Kai or the MacCluer Gulf. As at Dudumahan, anthropomorphs are often associated with boat images.

Boats are the next most frequently represented figurative elements and vary from simple schematized boats to fairly complex examples such as the x-ray boat at Lene Cécé (Fig. 2). One of the small boats from the Lene Cécé site (Fig. 23a) shows close stylistic similarities with the most clearly representational of the boats from Dudumahan (Fig. 23b) in the presence of the high prow and stern, decorated prow, the depiction of the central sail, the steering oar, and the standing figure with uplifted arms holding objects above its head. 


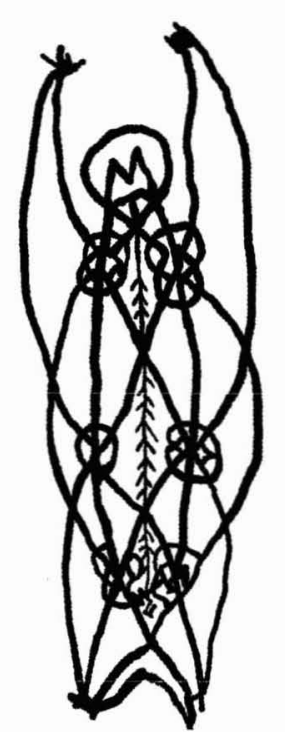

a

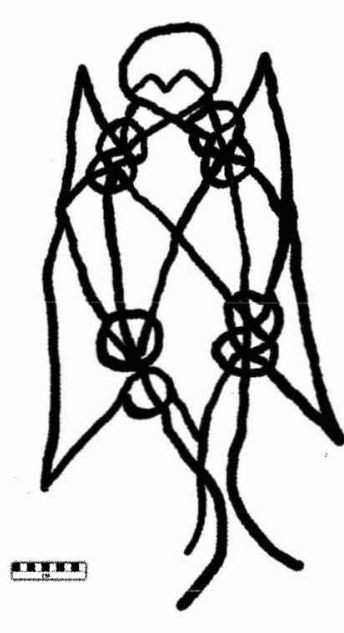

b

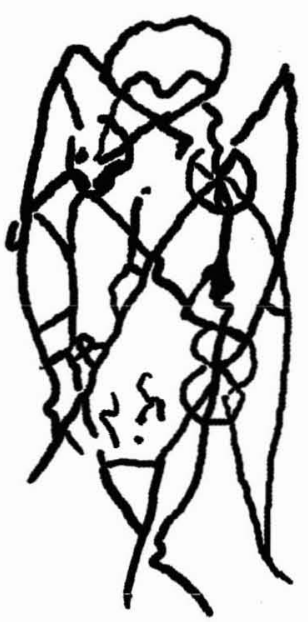

C

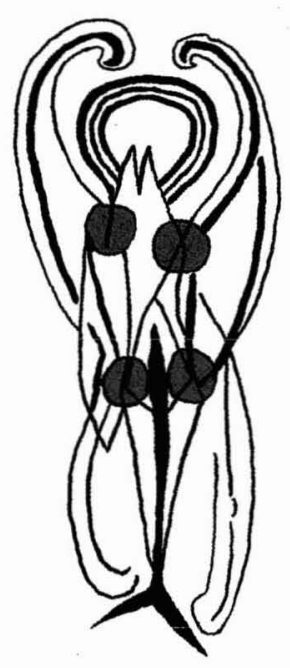

d

Fig. 24. a: Lene Hara x-ray fish-flying fox (red pigment); b: MacCluer Gulf x-ray fish-flying fox figures (red pigment), drawing by Hahn of motif in the Sora site (Röder 1959:144, pl. 17); c: MacCluer Gulf x-ray fish-flying fox figures (red pigment), the Sora site, original motif (Röder 1959: 160, pl. 2); d: MacCluer Gulf x-ray fish-flying fox figures (red pigment), drawing by Hahn of motif in the Uruan site (Röder 1959:149, pl. 7).

While lizard-crocodile figures and lizard-crocodile-anthropomorph figures and fish occur, they are not common as they are in the MacCluer Gulf sites. Fish are predominantly confined to Lene Hara although a partial fish is found at Lene Kici 1 (only the tail remains; the rest appears to have been removed by weathering). Other animals that are represented include turtles, horses, and birds. The example seen in Figure 2, above the boat, bears a striking resemblance to a cassowary. The zoogeographic province of the genus Casuarius is New Guinea-Northern Australia and the Aru Islands (formerly part of Sahul). No species of Casuarius or other ratites occur in Timor today or have been identified in the Timorese faunal sequences, however, they occur in Seram, where they are thought to have been introduced as captive animals and are known to have been traded from New Guinea to Europe and Asia from at least the twelfth century (White 1975). The first live cassowary is reputed to have reached Europe in 1597, introduced by Dutch sailors who purchased it in Java (Salvadori 1882:481). These birds were no doubt both exotic and valuable, which may account for the depiction in the Timor rock panel.

Motifs such as the interlocking x-ray fish-outline flying fox at Lene Hara (Fig. 24a) conform so strongly to the Manga period "fish/flying fox" figures illustrated by Röder and his artist Hahn (Fig. 24b-d) that it seems incontrovertible that this is a culturally shared symbol. The overlapping representations and the paired circles perhaps suggests a link with clan affiliation.

Other linear decorative figures at Lene Hara (for example, Fig. 4), are similar to Manga complex linear motifs in MacCluer (Fig. 25a-b), Röder 1959 and see 


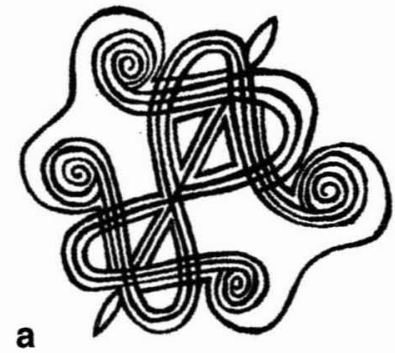

b
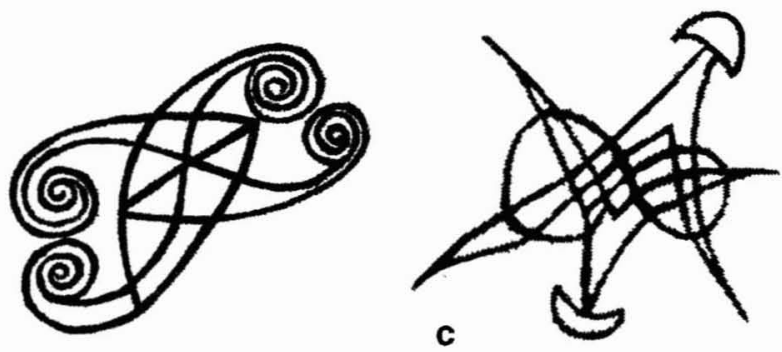

Fig. 25. Scrolled and linear decorations drawn by Hahn, based on motifs from the MacCluer Gulf (Röder 1959): a-b: 1959:124, pl. 2; c: 1959:125, pl. 2) (color of original motifs not specified).

also Ballard 1988:147, figs. 5v and 5viii) and the polychrome complex linear motif that includes green pigment at Lene Hara (Fig. 7, right) also has parallels in the MacCluer Gulf (Fig. 25c).

While representational motifs such as anthropomorphs with weapons and tools, boats, and fish occur in several of the East Timor sites, each is distinctive. Ballard (1988:152) also noted his attempts to classify the Dudumahan motifs were frustrated by a lack of internal patterning.

In fact, comparisons with other regions such as the MacCluer Gulf sites and the Kai sites show as strong affinities between motifs in these different regions as within or between the East Timor sites. The fish/flying fox motifs of Lene Hara and the MacCluer Gulf, and some of the boats from Lene Kici 1 and Lene Cécé compare favorably with those from Kai Kecil.

\section{Color Sequencing and Chronology}

As in all painted art sites recorded in the western Pacific region there is an overwhelming dominance in the use of red pigment in the East Timor sites, followed by the use of black pigment. While many of the sites have little or no superposition, wherever superposition does occur the color sequence is always the same as that identified by Ballard at Dudumahan, black over red. More tentatively it is possible to say that in the few instances of red-yellow superposition, it is red over yellow rather than yellow over red. However, there is no strict relationship between color and chronology as several motifs include black, red, and yellow and a few also incorporate green.

Variation in the hues of red or orange-yellow can be due to differential preservation or exposure. In some cases, this has resulted in what was originally red pigment fading to light orange-yellow-brown hues. An example can be seen at Lie Kere 1 located by Glover (1972) (Fig. 8). Here the creeper motif has largely faded to orange/yellow but the tips of the leaves are still bright vermilion. However, in other cases, the yellow painting clearly results from the use of yellow pigment, rather than fading.

Black art occurs as dry pigment (drawing) sketchily covering the rock surface as well as wet pigment (Fig. 14c). A good example of black dry pigment is the boat and anthropomorph panel at Vérulu (Fig. 18).

Several factors would suggest that the color sequence in the East Timor sites may not have a great deal of time depth. For example, the polychrome mask at Ile 


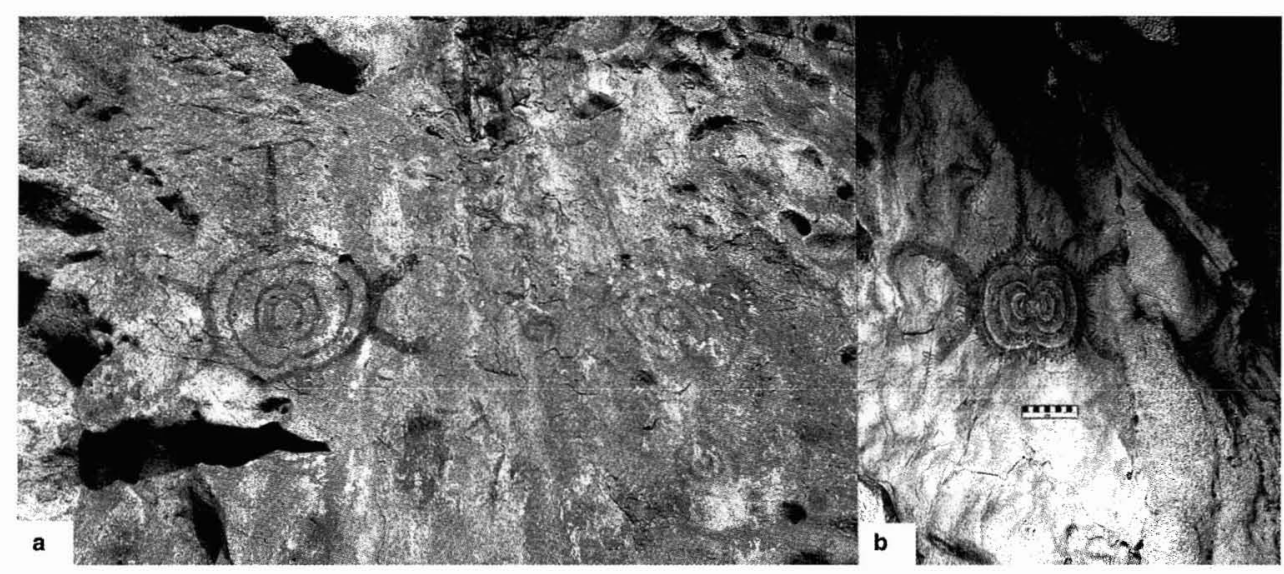

Fig. 26. Ile Kere Kere: mask motif in faded red pigment and polychrome (red, black, yellow, and green).

Kere Kere appears very fresh and incorporates red, black, yellow, and green pigment, however identical "mask" motifs in faded red are seen alongside the polychrome mask (Fig. 26). Without direct dating it is not possible to say whether the red mask motifs are earlier and the mask motif has had continuity through time or whether the red motifs are simple versions of the mask motif and all are contemporary. Some of the anthropomorphs at Ile Kere Kere executed in red pigment, which are stylistically similar to other red anthropomorphs in East Timor and at Dudumahan, are shown riding horses and may date to the historic period.

\section{Dong Son Influences}

Röder, Glover, Rosenfeld, and Ballard have all commented on the similarity of some of the motifs in western Pacific painting sites to motifs found on Dong Son artifacts. Ballard (1992) reasoned that the virtual confinement of painting sites to AN-speaking areas and the apparent symbolic and functional coherence of this group of rock art suggested its production by Austronesians after their arrival in Western Melanesia, sometime after 4000 B.P. He further reasoned that the similarities between the motifs in the painted rock art and some Metal Age artifacts, such as Dong Son drums, suggested an age for the art closer to 2000 B.P.

Röder originally reported the stenciling of Dong Son axes in his early red phase but thought that as these items were venerated at the time of his visit the paintings could have been executed at any time since the acquisition of axes. Rosenfeld points to the similarity of the "ship of the dead" motif in some of the stylized boats in the Arguni phase, which she believes may provide a better time frame. However, even this is uncertain as the ship of the dead motif occurs on contemporary craft objects and cloth in Island Southeast Asia.

Some features of the large Lene Cécé $\mathrm{x}$-ray boat (Fig. 2) resemble those on the war canoes depicted on the shoulders or mantle or Dong Son bronze drums. These drums originated in production centers in Viet Nam about 2000 years ago, have been found throughout eastern Indonesia as far east as the Bird's Head of Papua (Spriggs and Miller 1988). Akerman and Dwyer (2000) comment that the 

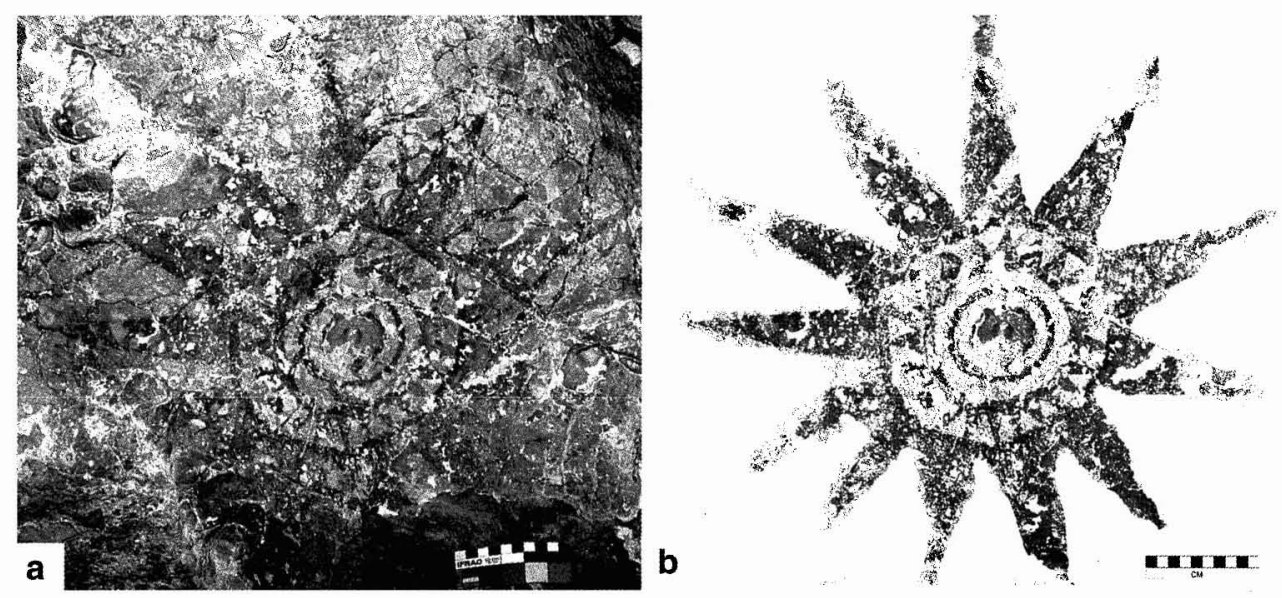

Fig. 27. Lene Hara: rayed circle-sun in red pigment, photograph (left) and drawing from photograph (right).

war boats on the drums show warriors wearing "elaborate plumed headgear" and carrying weapons. "The boats themselves are depicted as long slim craft with elaborate bow and stern decorations. Most characteristically the prows are high, and vertical or raked back, and richly carved in the likeness of a dragon, while the bows support prominent occuli" (Akerman and Dwyer 2000:87). The large boat depicted at Lene Cécé has a high raked prow (Fig. 2). Kempers (1988) provides a detailed inventory of the boats found on Dong Son drums. The more detailed naturalistic depictions are found on the earlier drums. On the later types, the decoration becomes highly stylized. Although no drums have been found in Timor, their distribution includes Flores, Roti, and Alor as well as Leti, just off the east end of Timor. Spriggs and Miller (1988:86) note that the eastern Indonesia drums are of the late Heger I period and date to the third century A.D. The boats on these drums are much more schematized than the red painted boats in the Timor and Kai rock art panels.

The interlocking heart-shaped and scissor scrolls found in the Manga style in MacCluer Gulf, in Lene Hara, and Ile Kere Kere (Ballard 1988:147, 5v, 5viii) are a common design element in the cartouches on the tympanums of Dong Son drums. The rayed sun motif at Lene Hara (Fig. 27) also bears comparison with the rayed solar stars in the center of tympanums, however, those usually have the chevron pattern outside the solar star, which is depicted as a solid mass, whereas the Lene Hara example has the internal area of the circle decorated. As noted above, simpler versions of this motif also occur on recent painted pottery in West Timor and on contemporary craft goods. Spiral scrolling is ubiquitous in Polynesian carving and facial tattooing.

\section{DISCUSSION AND FUTURE RESEARCH}

The East Timor painting sites can be readily encompassed within what Ballard has called the "Austronesian painting tradition." In fact, more stylistic affinities can be found in comparisons with other sites in the western Pacific region than can be 
found within individual sites or between sites within East Timor. Features that set the East Timor sites apart are primarily the few hand or other stencils and their near confinement to the interior areas of deep caves at some distance from the coast. These main features of the East Timor painted rock art can be summarized as follows.

1. A distinct group of motifs in deep accessible locations includes hand stencils, geometrics, and simple red figurative motifs. This group is set apart on the basis of its distribution. However, there is no evidence that this grouping is separated chronologically from the art on the exposed sea-cliff panels-it may simply have served a different function.

2. Another group of motifs has strong visual connections to the Manga style in the MacCluer Gulf. The motif matches are so good, and some of the designs so complex, that it does not seem possible that this is a random occurrence. It seems certain that this co-occurrence indicates some type of interaction across this region, although the design elements may have been transmitted through mediums other than painted rock art.

3. A third group of small anthropomorphs and boats has strong formal affinities with the red anthropomorphs and boats at Kai Kecil. Some of the anthropomorphs at Ile Kere Kere in this style are portrayed riding horses, possibly indicating a historic period execution.

4. Many of the simple geometric motifs are ubiquitous and span all color groups.

5. In terms of color positioning, black art overlies red art and never the reverse. However, this may have little chronological significance because:

a. Some of the red images incorporate historic subjects.

b. There is continuity in form and motif content between the red and black art.

c. Red and black are occasionally used in the same image and where this occurs the pigments appear to have been applied at the same time. Further, some fresh polychrome images closely mirror faded red motifs.

6. Most of the single motifs in black pigment are dry application with a few exceptions where pigment was applied wet.

7. The dry black art has fewer complex linear motifs. It consists of geometrics, latticing, lizard-crocodile figures, anthropomorphs, and boats.

8. While black is used in some of the complex linear motifs of the third phase that resemble the Manga style of MacCluer Gulf, the pigment appears to have been applied wet, to produce a fluid and unbroken line.

9. Figures such as the anthropomorph with exaggerated leg muscles at Vérulu are outliers and have no other parallels in terms of size or style in the other painted rock art sites of East Timor or with Kai or the MacCluer Gulf sites. They are reminiscent of the late Polynesian figurative style, such as the full frontal figures found in Hawai' $i$ and New Zealand.

10. It is possible that the different styles were concurrent but fulfilled different functions.

Without implying any spatial, chronological, or social connection between them, there may be synergies in the operation of the painted art tradition of the western Pacific and the operation of the Lapita system. As has been documented at length, the technology and style of Lapita pottery changed over the 1000 years or so of its 
existence. These changes occurred in parallel over the area of its distribution from the Bismarcks to Samoa. However this interaction was "more subtle than simple trade or exchange of archaeologically visible material goods" (Thomson and White $2000: 317$ ) as mineralogical analyses show that most pots were locally produced (Summerhayes 2000). Such parallel changes have been argued to "reflect changes in the social network and indicate continuing interaction between these communities." Exactly what form this "interaction" took is unclear but the evidence suggests that the motifs on Lapita functioned as some form of socialideological signifiers "conveying information, fostering group identity, and maintaining social boundaries" (Summerhayes 2000:303). The discovery of clay figurines with similar dentate markings on the face and buttocks has raised the idea that such motifs may replicate tattooing and define clan affiliations (Summerhayes $2000: 304)$. Similarly, the inclusion of Dong Son drums into an eastern Indonesia network may have operated at a level more complex than the mercantile, but exactly what type of network is implied is uncertain. Spriggs and Miller (1988:86) suggest that the drums may have been used, "to cement alliances between foreign traders or emissaries and local elites rather than entering exchange networks directly."

There has been a lot of discussion about the function of rock art as a symbolic signifier to maintain social boundaries or to empower the operation of 'open' social networks or alliances such as the ones assumed to have operated to produce the system that is now identifiable as Lapita or which led to the spread over vast distances of Dong Son material culture. Hodder (1982:202) draws our attention to the fact that many such analyses are not in fact such at all, in that they fail at a theoretical level to produce any connection between the material symbol or marker and the operation of the system; be it exchange, clan alliance, or whatever else. At their worst, such studies also fail at the material level in that they are grossly oversimplified. Hodder (1982:202) uses the example of Spondylus shells, exchanged widely into Central Europe during the Neolithic with a distribution over $1000 \mathrm{~km}$ wide to illustrate his point. "Towards the eastern end of the distribution in the Nitra cemetery, these shells occur mainly in the graves of males over 30-40 years of age. Yet in north-central France, Spondylus shells are found in Bandkeramik graves only with women." Despite the fact that these shells clearly had different meanings "in two local contexts within the same broad culture area" their distribution has been used to track "total exchange networks."

This brief overview of the painted art of East Timor and the comparison with sites elsewhere in the broader region of the western Pacific has perhaps identified some connections documented in the rock paintings. Our challenge for the future is to go further than merely plotting similarities between motif classes or identifying formal stylistic affinities. It will be to try to understand the nature of these connections within local and broader contexts.

When Specht attempted an overview of the rock art of the western Pacific in 1979 he stated that the majority of the sites needed to be reexamined in the field, and information on design content, location and composition recorded, prior to any stylistic synthesis (Specht 1979:75). Since this time, detailed analyses of parts of this broad region have begun, making even more obvious the size of the task ahead (Ballard 1988; Wilson 2002). In the future it is to be hoped that dating of the rock art, recording and analysis of the art context and motifs, in tandem with 
research on the archaeological deposits, might lead the way forward to an understanding of the way in which the rock paintings functioned across this broad sphere of interaction, namely the western Pacific. Rock art recording in East Timor is planned for 2002 .

\section{ACKNOWLEDGMENTS}

I would particularly like to thank my co-worker, Sandra Pannell, who drew my attention to the faded paintings on the walls of Vérulu. The fieldwork was undertaken under the auspices of the East Timor Archaeological Project and was funded by a large grant (with my co-workers Matthew Spriggs and Peter Veth) from the Australian Research Council. The people of Tutuala and in particular the landowner of the painted art sites in the Tutuala region, Paolo Da Costa, were very helpful with access. Amaduro Sampaiyo, the Kepala Desa at Mehara in July 2001, gave assistance, and Armindo $\mathrm{Da}$. Costa and Marselino Do Carmo took me to Vérulu. Meredith Wilson and Andrée Rosenfeld helped out with references and discussed ideas. John Bowden, Department of Linguistics, gave advice on current language boundaries in East Timor.

\section{NOTE}

1. This is a common form of axe in Southeast Asia, particularly Java, and is usually attributed to the Southeast Asian Bronze Age, although few have been found in datable contexts in Indonesia. Interestingly, Glover (1989) speculates that this axe may have been smelted in Timor because the copper content is so high.

\section{REFERENCES CITED}

Akerman, Kim, and Dan Dwyer

2000 The Senabi: External stern-lashings on Austronesian water-craft. Bulletin of the Australian Institute of Maritime Archaeology 24:85-88.

Almeida, A. De

1967 A contribution to the study of rock paintings in Portuguese Timor, in Archaeology at the Eleventh Pacific Science Congress: Papers Presented at the XI Pacific Science Congress, Tokyo, August-September 1966: 69-76, ed. W. G. Solheim II. Asian and Pacific Archaeology Series 1. Honolulu: Social Science Research Institute, University of Hawai'i.

Almeida, A. De, and G. Zbyszewski

1967 A contribution to the study of the prehistory of Portuguese Timor-lithic industries, in Archaeology at the Eleventh Pacific Science Congress: Papers Presented at the XI Pacific Science Congress, Tokyo, August-September 1966: 55-67, ed. W. G. Solheim II. Asian and Pacific Archaeology Series 1. Honolulu: Social Science Research Institute, University of Hawai'i.

BALLARD, Chris

1988 Dudumahan: A rock art site on Kai Kecil, S.E. Moluccas. IPPA Bulletin 8:139-161.

1992 Painted rock art sites in western Melanesia: Locational evidence for an 'Austronesian' tradition, in State of the Art Regional Rock Art Studies in Australia and Melanesia: 94-106, ed. J. McDonald and I. Haskovec. Occasional AURA Publication No. 6. Melbourne: Australian Rock Art Research Association.

Berger-Kircher, L.

1970 The rock art of west New Guinea, in The Art of the Stone Age: 231-239, ed. H. G. Bandi et al. London: Methuen.

Cinatti, R.

1963 As Pinturas Rupestres de Timor. Lisbon: Coloquio.

David, B. J., I. Brayer, I. Mcniven, and A. Watchman

2001 Why digital enhancement of rock paintings works: Rescaling and saturating colors. Antiquity $75: 781-792$. 
Glover, Ian

1972 Excavations in Timor. Ph.D. diss., Department of Prehistory Research School of Pacific Studies. Canberra: Australian National University.

1986 Archaeology in Eastern Timor, 1966-67. Terra Australis 11. Canberra: Department of Prehistory Research School of Pacific Studies, Australian National University.

1989 The prehistoric background to Timorese culture. Unpublished paper presented at the Colloquio Timor, Museo de Etnologia, Lisbon 11-15 October.

Hajek, John, and Nikolaus Himmlemann

2001 A report on the current linguistic situation in the Lautem region (East Timor). Studies in East Timorese Languages and Cultures 4:88-97.

HODDER, IAN

1982 Symbols in Action. Ethnoarchaeological Studies of Material Culture. Cambridge: Cambridge University Press.

Kempers, A.J.B.

1988 The kettledrums of Southeast Asia: A Bronze Age world and its aftermath, in Modern Quaternary Research in Southeast Asia: 10, eds. G. J. Bartstra and W. A. Casparie. Rotterdam: A. A. Balkema.

LEE, G., AND E. STASACK

1999 Spirit of Place Petroglyphs of Hawai $i$. Easter Island Foundation. Los Osos, CA: Bearsville and Cloud Mountain Presses.

O'CONNOR, SUE

2002 Pleistocene Timor: Further corrections, a reply to Bednarik. Australian Archaeology $54: 46-51$.

O’Connor, Sue, Matthew Spriggs, and Peter Veth

2002 Excavation at Lene Hara establishes occupation in East Timor 30,000-35,000 years ago. Antiquity $76: 45-50$.

n.d. Direct dating of shell beads from Lene Hara Cave, East Timor. Australian Archaeology. In press.

RÖDER, JOSEF

1956 The rock paintings of the MacCluer Bay. Antiquity and Survival $1: 387-400$.

1959 Felsbilder und Vorgeschichte des MacCluer-Golfes, West-Neuguinea. Ergebnisse der Frobenius-Expedition 1937-38, in Die Molukken und nach Holländisch Neu-Guinea. Darmstadt: L. C. Wittich.

ROSENFELD, ANDRÉ

1988 Rock art in western Oceania. IPPA Bulletin 8:119-138.

1997 Archaeological signatures of the social context of rock art production, in Beyond Art: Pleistocene Image and Symbol: 289-300, ed. M. Conkey, O. Soffer, D. Stratmann, and N. Jablonski. Memoirs of the California Academy of Sciences No. 23. San Francisco, California.

SALVADORI, $\mathrm{T}$.

1882 Ornithologia della Papuasia e della Molucche 3:473-501. Torino.

SPECHT, JiM

1979 Rock Art in the Western Pacific, in Exploring the Visual Art of Oceania: Australia, Melanesia, Micronesia and Polynesia: 59-82, ed. S. M. Mead. Honolulu: University of Hawai'i Press.

Spriggs, Matthew, and Danny Miller

1988 A previously unreported bronze kettledrum from the Kai Islands, Eastern Indonesia. IPPA Bulletin 8:79-89.

SumMerhayes, GLENN

2000 What's in a pot, in Australian Archaeologist Collected Papers in Honour of Jim Allen: 291-307, ed. A. Anderson and T. Murray. Canberra: Centre for Archaeological Research and Department of Archaeology and Natural History, Australian National University.

Thomson, J. R., AND J. P. White

2000 Localism of Lapita pottery in the Bismarck Archipelago, in Australian Archaeologist Collected Papers in Honour of Jim Allen: 291-307, ed. A. Anderson and T. Murray. Canberra: Centre for Archaeological Research and Department of Archaeology and Natural History, Australian National University. 
VAN Es, L.J.C.

1921 Indlandsche Koperertsontginningen op Timor. Tijdschrift van het Koninklijk Nederlandsch Aardrijkskundig Genootschap (Ser.2) 38:808-810.

White, C.M.N.

1975 The problem of the cassowary in Seran. Bulletin of the British Ornithologists' Club 95(4): $165-170$.

WILSON, MEREDITH

2002 Picturing Pacific Prehistory: The Rock Art of Vanuatu in a Western Pacific Context. Ph.D. diss. Canberra: Australian National University.

n.d. Rethinking regional analyses of western Pacific rock-art. Records of the Australian Museum. In press.

\section{ABSTRACT}

Few rock art sites are known for the islands of Wallacea. This paper reports nine new painted rock art sites located in East Timor during archaeological reconnaissance in 2000 to 2001; bringing the total number of painted rock art sites in East Timor to 15. Both the new and previously known rock art sites in East Timor are reviewed in the context of painted rock art elsewhere in the western Pacific region. They are also evaluated in terms of the criteria used by Ballard (1992) to define the "Austronesian painting tradition" and the relationship between the art, topography, and language groups for the new sites is described. Motif content, motif placement within the sites, and design elements are compared in a preliminary fashion with that of other painting sites known from East Timor and the western Pacific. The East Timor sites are conformable with Austronesian-painted rock art sites elsewhere although they display some features that appear to be locally or regionally distinctive. It is likely that with systematic survey, and thorough inspection of cave and shelter walls, many more sites will be found in East Timor and elsewhere in Island Southeast Asia. The faded and deteriorated condition of many of the East Timor paintings indicates that recording should be undertaken with some urgency. KeYwords: painted rock art, East Timor, Island Southeast Asia, Western Pacific, Austronesian painting tradition. 